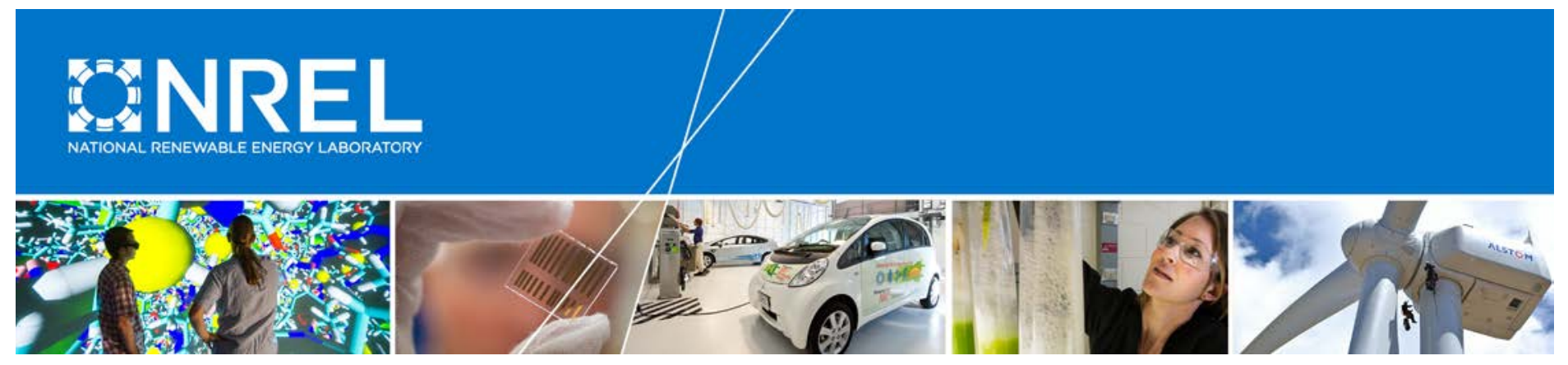

\title{
Power Quality Test Report for the U.S. Department of Energy 1.5-Megawatt Wind Turbine
}

Ismael Mendoza, Jerry Hur, and Syhoune Thao National Renewable Energy Laboratory

NREL is a national laboratory of the U.S. Department of Energy Office of Energy Efficiency \& Renewable Energy Operated by the Alliance for Sustainable Energy, LLC

This report is available at no cost from the National Renewable Energy Laboratory (NREL) at www.nrel.gov/publications.

Technical Report

NREL/TP-5000-63686

August 2015

Contract No. DE-AC36-08G028308 


\section{Power Quality Test Report for the U.S. Department of Energy 1.5-Megawatt Wind Turbine}

Ismael Mendoza, Jerry Hur, and Syhoune Thao National Renewable Energy Laboratory

Prepared under Task No. WE15.1A02
NREL is a national laboratory of the U.S. Department of Energy Office of Energy Efficiency \& Renewable Energy Operated by the Alliance for Sustainable Energy, LLC

This report is available at no cost from the National Renewable Energy Laboratory (NREL) at www.nrel.gov/publications.

\section{Technical Report}

NREL/TP-5000-63686

August 2015

Contract No. DE-AC36-08G028308
National Renewable Energy Laboratory 5013 Denver West Parkway

Golden, CO 80401

303-275-3000 • www.nrel.gov 


\section{NOTICE}

This report was prepared as an account of work sponsored by an agency of the United States government. Neither the United States government nor any agency thereof, nor any of their employees, makes any warranty, express or implied, or assumes any legal liability or responsibility for the accuracy, completeness, or usefulness of any information, apparatus, product, or process disclosed, or represents that its use would not infringe privately owned rights. Reference herein to any specific commercial product, process, or service by trade name, trademark, manufacturer, or otherwise does not necessarily constitute or imply its endorsement, recommendation, or favoring by the United States government or any agency thereof. The views and opinions of authors expressed herein do not necessarily state or reflect those of the United States government or any agency thereof.

This report is available at no cost from the National Renewable Energy Laboratory (NREL) at www.nrel.gov/publications.

Available electronically at SciTech Connect http:/www.osti.gov/scitech

Available for a processing fee to U.S. Department of Energy and its contractors, in paper, from:

U.S. Department of Energy

Office of Scientific and Technical Information

P.O. Box 62

Oak Ridge, TN 37831-0062

OSTI http://www.osti.gov

Phone: 865.576.8401

Fax: 865.576.5728

Email: reports@osti.gov

Available for sale to the public, in paper, from:

U.S. Department of Commerce

National Technical Information Service

5301 Shawnee Road

Alexandria, VA 22312

NTIS http://www.ntis.gov

Phone: 800.553 .6847 or 703.605 .6000

Fax: 703.605.6900

Email: orders@ntis.gov 


\title{
Power Quality Test Report
}

for the

\section{DOE 1.5-MW Wind Turbine}

in

\author{
Golden, Colorado, USA
}

Conducted for

\begin{abstract}
U.S. Department of Energy Office of Energy Efficiency and Renewable Energy
Wind and Water Power Program

Forrestal Building

1000 Independence Avenue, SW

Washington, DC 20585

Conducted by

National Wind Technology Center

National Renewable Energy Laboratory

15013 Denver West Parkway

Golden, Colorado 80401
\end{abstract}

Ismael Mendoza, Jerry Hur, and Simon Thao

February 24, 2015 


\section{Notice}

This report was prepared by the National Renewable Energy Laboratory (NREL), operated for the United States Department of Energy (DOE) by the Alliance for Sustainable Energy, LLC (Alliance), as an account of work sponsored by the United States government. The test results documented in this report define the characteristics of the test article as configured and under the conditions tested.

THIS REPORT IS PROVIDED "AS IS" AND NEITHER THE GOVERNMENT, ALLIANCE, NREL NOR ANY OF THEIR EMPLOYEES, MAKES ANY WARRANTY, EXPRESS OR IMPLIED, INCLUDING THE WARRANTIES OF MERCHANTABILITY AND FITNESS FOR A PARTICULAR PURPOSE, OR . ASSUMES ANY LEGAL LIABILITY OR RESPONSIBILTTY FOR THE ACCURACY, COMPLETENESS, OR USEFULNESS OF ANY SUCH INFORMATION DISCLOSED IN THE REPORT, OR OF ANY APPARATUS, PRODUCT, OR PROCESS DISCLOSED, OR REPRESENTS THAT ITS USE WOULD NOT INFRINGE PRIVATELY OWNED RIGHTS.

Neither Alliance nor the U. S. Government shall be liable for special, consequential or incidental damages. Reference herein to any specific commercial product, process, or service by trade name, trademark, manufacturer, or otherwise does not necessarily constitute or imply its endorsement, recommendation, or favoring by the United States government or any agency thereof. The views and opinions of the authors expressed herein do not necessarily state or reflect those of the United States government or any agency thereof or Alliance.

NREL is a DOE Laboratory, and as an adjunct of the United States government, cannot certify wind turbines. The information in this report is limited to NREL's knowledge and understanding as of this date.

NREL is accredited by the American Association for Laboratory Accreditation (A2LA) and the results shown in this test report have been determined in accordance with the NREL's terms of accreditation unless stated otherwise in the report.

This report shall not be reproduced, except in full, without the written approval of Alliance or successor operator of NREL.

Approval By:
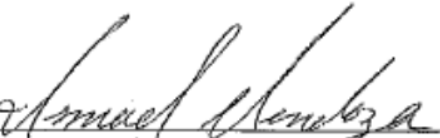

I. Mendoza, NREL Test Engineer

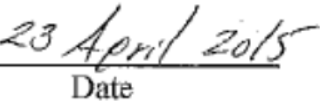

Review By:

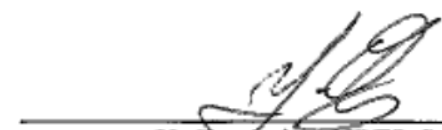

V. Gororgian, NREL Senior Engineer

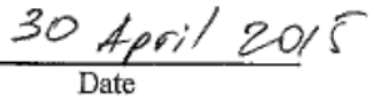




\section{Table of Contents}

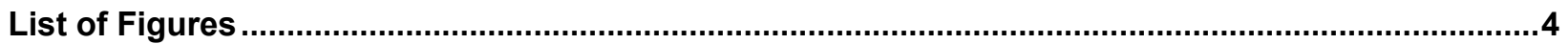

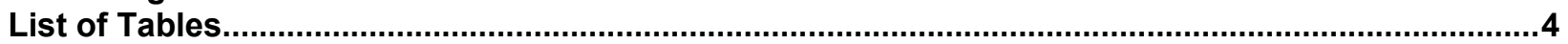

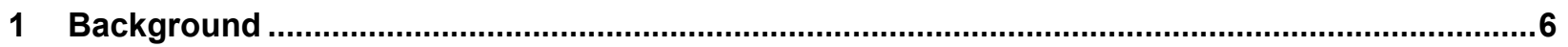

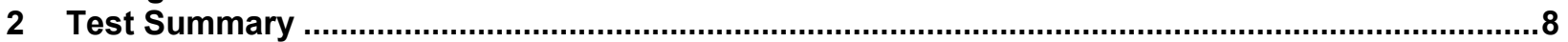

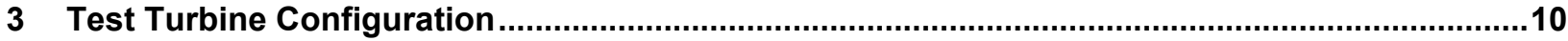

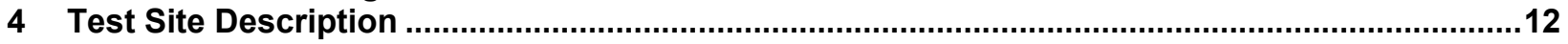

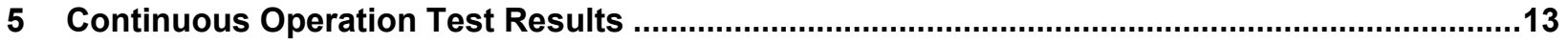

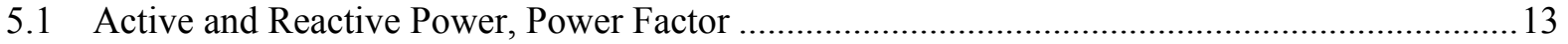

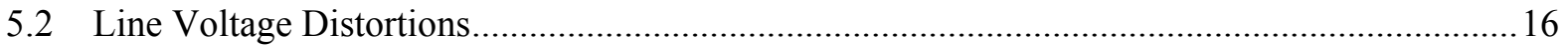

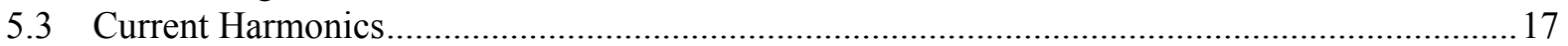

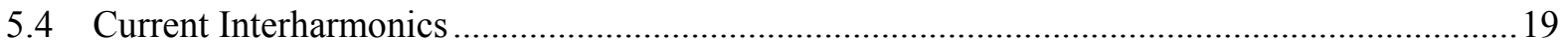

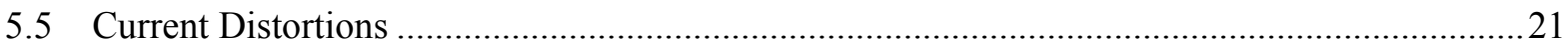

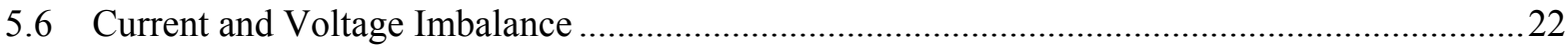

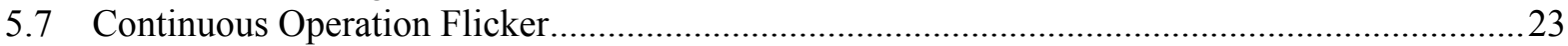

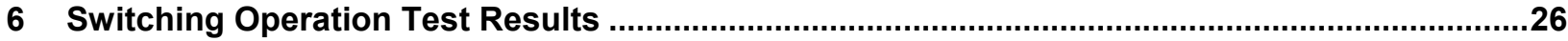

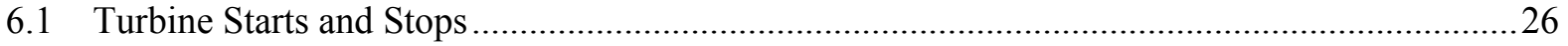

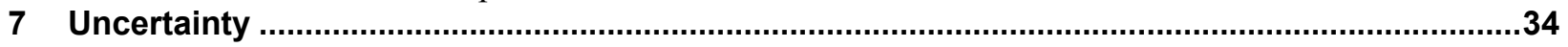

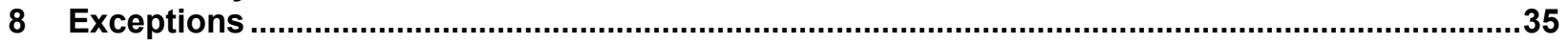

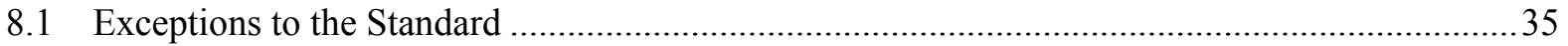

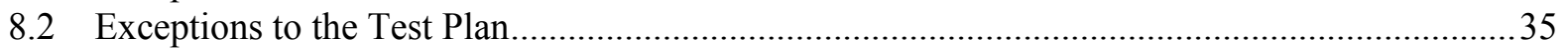

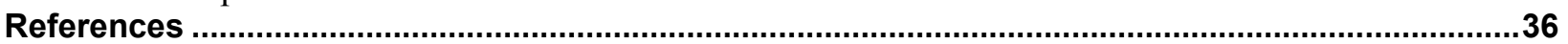

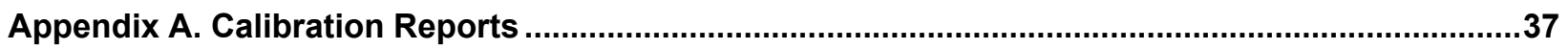

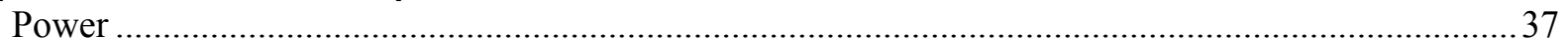

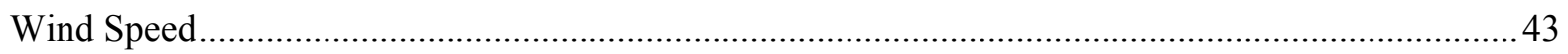




\section{List of Figures}

Figure 1. DOE 1.5 at the NWTC. Photo by Jeroen van Dam, NREL …..................................................... 11

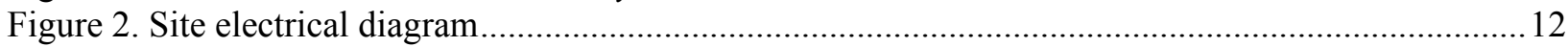

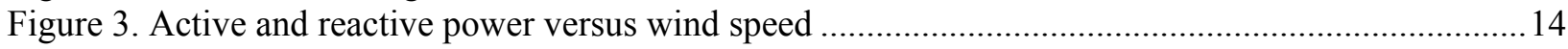

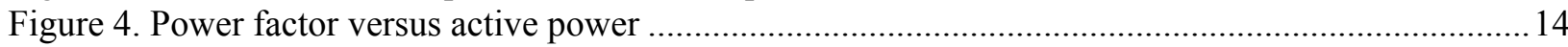

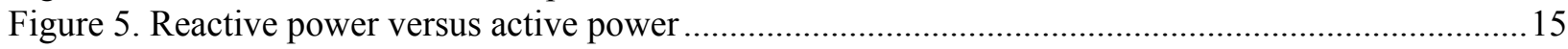

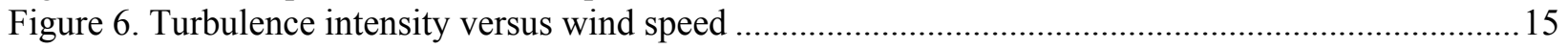

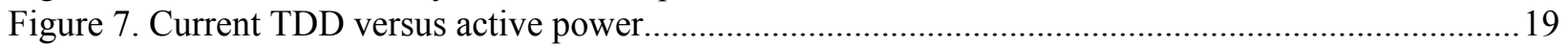

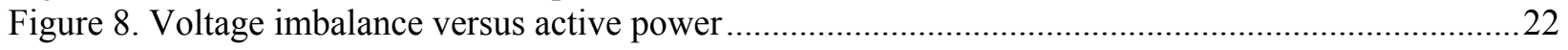

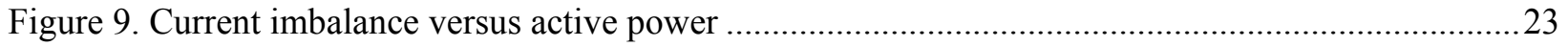

Figure 10. Short-term flicker $\left(\mathrm{P}_{s t}\right)$ versus power for $30^{\circ}$ network impedance angle ..............................23

Figure 11. Short-term flicker $\left(\mathrm{P}_{s t}\right)$ versus power for $50^{\circ}$ network impedance angle ................................24

Figure 12. Short-term flicker $\left(\mathrm{P}_{s t}\right)$ versus power for $70^{\circ}$ network impedance angle ...............................24

Figure 13. Short-term flicker $\left(\mathrm{P}_{s t}\right)$ versus power for $85^{\circ}$ network impedance angle .................................24

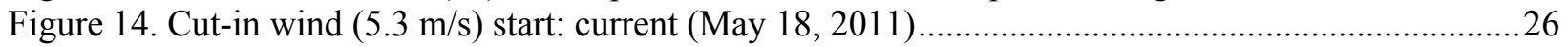

Figure 15. Cut-in wind $(5.3 \mathrm{~m} / \mathrm{s})$ start: power and RMS voltage (May 18, 2011) ..................................27

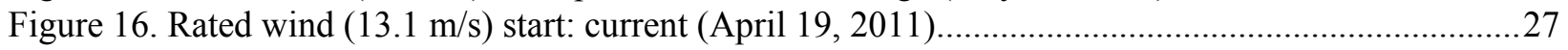

Figure 17. Rated wind $(13.1 \mathrm{~m} / \mathrm{s})$ start: power and RMS voltage (April 19, 2011) ...............................28

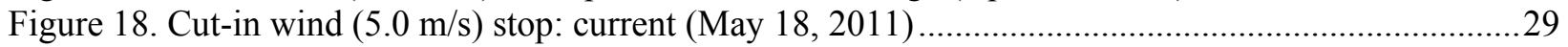

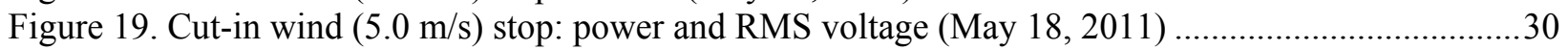

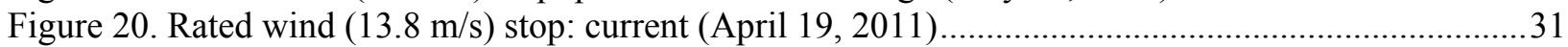

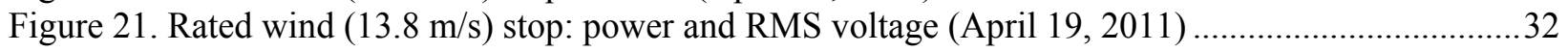

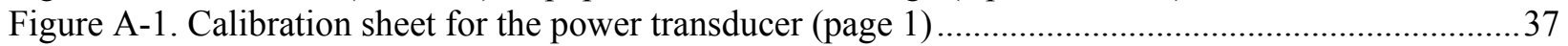

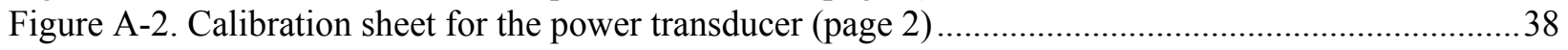

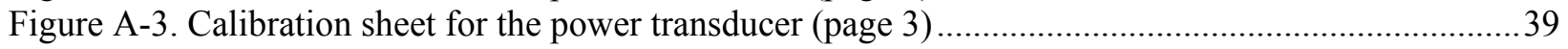

Figure A-4. Calibration sheet for the power transducer (page 4) ....................................................40

Figure A-5. Calibration sheet for the power transducer (page 5) ..........................................................41

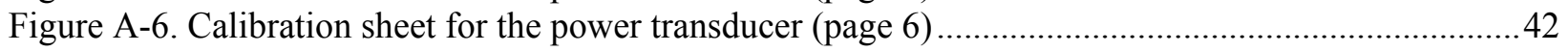

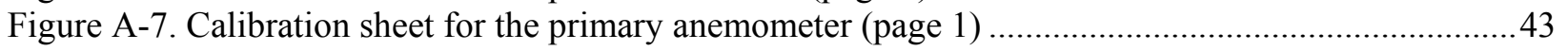

Figure A-8. Calibration sheet for the primary anemometer (page 2) ................................................4

Figure A-9. Calibration sheet for the primary anemometer (page 3) ...................................................45

Figure A-10. Calibration sheet for the primary anemometer (page 4) ...............................................46

Figure A-11. Calibration sheet for the primary anemometer (page 5) .................................................4

\section{List of Tables}

Table 1. Power Quality Capture Test Matrix Requirements Fulfilled................................................... 8

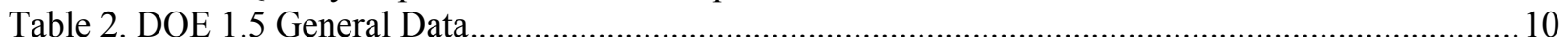

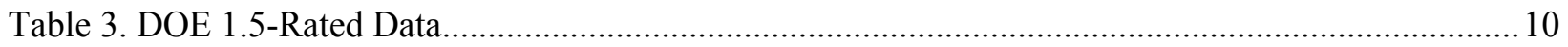

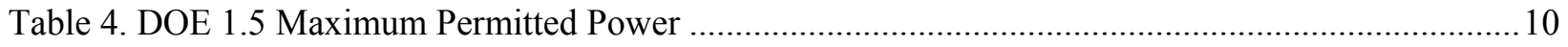

Table 5. Number of Data Points per 1-m/s Wind Speed Bins ............................................................... 13

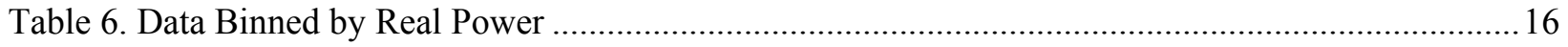

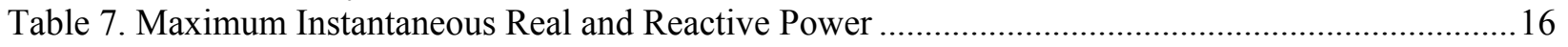

Table 8. Maximum Current Harmonics (10-Minute Averages) …........................................................... 18

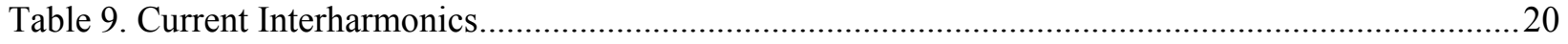

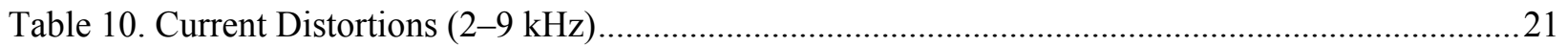

Table 11. Resulting Flicker Coefficients $c\left(\Psi_{k}, V_{a}\right)$ in Continuous Operation...........................................25

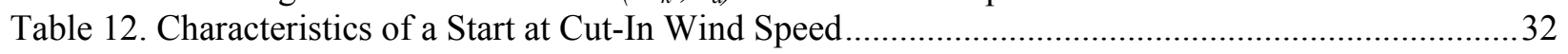

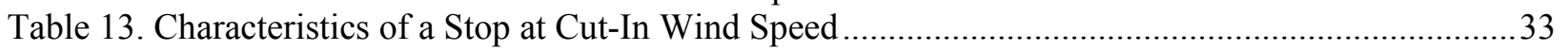

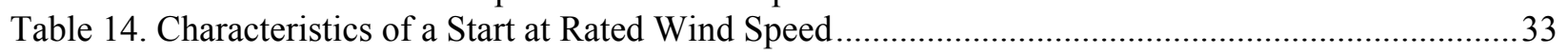


Table 15. Characteristics of a Stop at Rated Wind Speed.

Table 16. Uncertainty Analysis of the Measuring System. 


\section{Background}

The U.S. Department of Energy (DOE) acquired and installed a 1.5-megawatt (MW) wind turbine at the National Wind Technology Center (NWTC) at the National Renewable Energy Laboratory. This turbine (hereafter referred to as the DOE 1.5) is envisioned to become an integral part of the research initiatives for the DOE Wind Program, such as Atmosphere to Electrons (A2e). A2e is a multiyear DOE research initiative targeting significant reductions in the cost of wind energy through an improved understanding of the complex physics governing wind flow into and through wind farms. For more information, visit http://energy.gov/eere/wind/atmosphere-electrons.

To validate new and existing high-fidelity simulations, A2e must deploy several experimental measurement campaigns across different scales. Proposed experiments include wind tunnel tests, scaled field tests, and large field measurement campaigns at operating wind plants. Data of interest includes long-term atmospheric data sets, wind plant inflow, intra-wind plant flows (e.g., wakes), and rotor loads measurements. It is expected that new, high-fidelity instrumentation will be required to successfully collect data at the resolutions required to validate the high-fidelity simulations.

The large-scale field measurement campaigns are expected to use the DOE 1.5 as it is of sufficient enough size to represent current technology, and turbines of this size are widely deployed in U.S. wind plants.

Expected future use of the DOE 1.5 at the NWTC may include the following (leading up to the large files measurement campaigns at operating plants):

- Deployment and validation of high-fidelity instrumentation prior to large-scale deployment at a wind plant

- Deployment of advanced controls algorithms

- Characterization of inflow, aerodynamics, turbine loads, and wake propagation on an unwaked turbine.

A series of tests were conducted to characterize the baseline properties and performance of the DOE 1.5 to enable research model development and quantify the effects of future turbine research modifications.

The tests included:

- Power performance per International Electrotechnical Commission (IEC) 6140012-1

- $\quad$ Power quality per IEC 61400-21

- Acoustic noise per IEC 61400-11 
- Mechanical loads per IEC 61400-13

- Modal testing.

The DOE 1.5 is built on the platform of GE's 1.5-MW SLE commercial wind turbine model. It was installed in a nonstandard configuration at the NWTC with the objective of supporting DOE Wind Program research initiatives such as A2e. Therefore, the test results may not represent the performance capabilities of other GE 1.5-MW SLE turbines.

This report summarizes the analysis and results of the above-mentioned power quality test performed at the DOE 1.5. 


\section{Test Summary}

The NWTC conducted this power quality test in accordance with the International Electrotechnical Commission standard, IEC61400-21, Measurement and Assessment of Power Quality Characteristics of Grid Connected Wind Turbines, Edition 2.0, 2008-08 [1], hereafter referred to as the Standard. Standard procedures and the following test results required by the Standard are included in this report:

- Maximum measured power (600 seconds, 60 seconds, and 0.2 seconds)

- Reactive power demand

- Voltage fluctuations (flicker)

- Voltage harmonics, current harmonics, interharmonics, and distortions

- Turbine start and stop tests.

The DOE 1.5 power quality test began on March 15, 2011, and ended on May 2, 2011. 730 10-minute intervals of data were collected. The Standard requires at least five 10minute averaged data points for each $1 \mathrm{~m} / \mathrm{s}$ wind speed interval up to $15 \mathrm{~m} / \mathrm{s}$. The highest bin filled (without wind speed normalization) was the $16 \mathrm{~m} / \mathrm{s}$ bin. When the data was binned by percent of rated power, more than 5 data points were recorded for each bin. According to the Standard, sufficient data was collected. The capture test matrix is shown in Table 1.

Table 1. Power Quality Capture Test Matrix Requirements Fulfilled

\begin{tabular}{|l|c|c|}
\hline \multicolumn{1}{|c|}{ Test Type } & Measured & \multicolumn{1}{|c|}{$\begin{array}{c}\text { Required by } \\
\text { IEC 61400-21 }\end{array}$} \\
\hline $\begin{array}{l}\text { Continuous operation: } \\
\text { Number of 10-min intervals }\end{array}$ & $\begin{array}{c}\text { Five for each } \\
\text { bin }\end{array}$ & $\begin{array}{c}\text { At least five for each 1-m/s wind speed } \\
\text { bin up to 15 m/s }\end{array}$ \\
\hline $\begin{array}{l}\text { Switching operation: } \\
\text { Number of wind turbine starts (cut-in } \\
\text { wind speed) }\end{array}$ & Five & At least five \\
\hline $\begin{array}{l}\text { Switching operation: } \\
\text { Number of wind turbine stops (cut-in } \\
\text { wind speed) }\end{array}$ & Five & At least five \\
\hline $\begin{array}{l}\text { Switching operation: } \\
\text { Number of wind turbine starts (rated } \\
\text { wind speed) }\end{array}$ & Five & At least five \\
\hline $\begin{array}{l}\text { Switching operation: } \\
\text { Number of wind turbine stops (rated } \\
\text { wind speed) }\end{array}$ & Five & At least five \\
\hline
\end{tabular}

There were two identified exceptions to the Standard. The response to temporary voltage drop test and the grid protection test that are required by the second edition were not performed because the necessary test assets were not available in North America.

Also, because the necessary technical information was confidential and was not available from the manufacturer, the following tests were excluded from this testing campaign: 
- Power control

- Voltage drop response

- Grid protection and reconnection. 


\section{Test Turbine Configuration}

Table 2 to Table 4 list the technical data of the DOE 1.5 that was tested at the NWTC.

Table 2. DOE 1.5 General Data

\begin{tabular}{|l|r|}
\hline Turbine manufacturer and address & $\begin{array}{r}\text { GE Energy } \\
\text { Model }\end{array}$ \\
\hline Serial number & $\begin{array}{r}\text { Garlington Rd., P.O. Box 648 } \\
\text { Greenville, SC 29602-0648 }\end{array}$ \\
\hline Wind turbine type & GE 1.5 SLE \\
\hline Number of blades & No00780-N \\
\hline Hub height $(\mathrm{m})$ & Horizontal axis \\
\hline Blade control & 3 \\
\hline Rotor diameter $(\mathrm{m})$ & 80 \\
\hline Speed control & Pitch \\
\hline Generator type and rating (kW) & 77 \\
\hline Converter type & variable \\
\hline
\end{tabular}

Table 3. DOE 1.5-Rated Data

\begin{tabular}{|l|r|}
\hline Rated power, $P_{n}(\mathrm{~kW})$ & 1,500 \\
\hline Rated wind speed, $V_{n}(\mathrm{~m} / \mathrm{s})$ & 14 \\
\hline Rated apparent power, $S_{n}(\mathrm{kVA})$ & 1,666 \\
\hline Rated reactive power, $Q_{n}(\mathrm{kvar})$ & $+/-200$ \\
\hline Rated current, $I_{n}(\mathrm{~A})$ & 1,394 \\
\hline Rated voltage, $V_{n}(\mathrm{~V})$ & 690 \\
\hline Rated frequency, $f_{n}(\mathrm{~Hz})$ & 60 \\
\hline
\end{tabular}

Table 4. DOE 1.5 Maximum Permitted Power

\begin{tabular}{|l|r|}
\hline Peak continuous power, $P_{m c}(\mathrm{~kW})$ & 1,545 \\
\hline Normalized value, $p_{m c}=P_{m d} / P_{n}$ & 1.03 \\
\hline
\end{tabular}




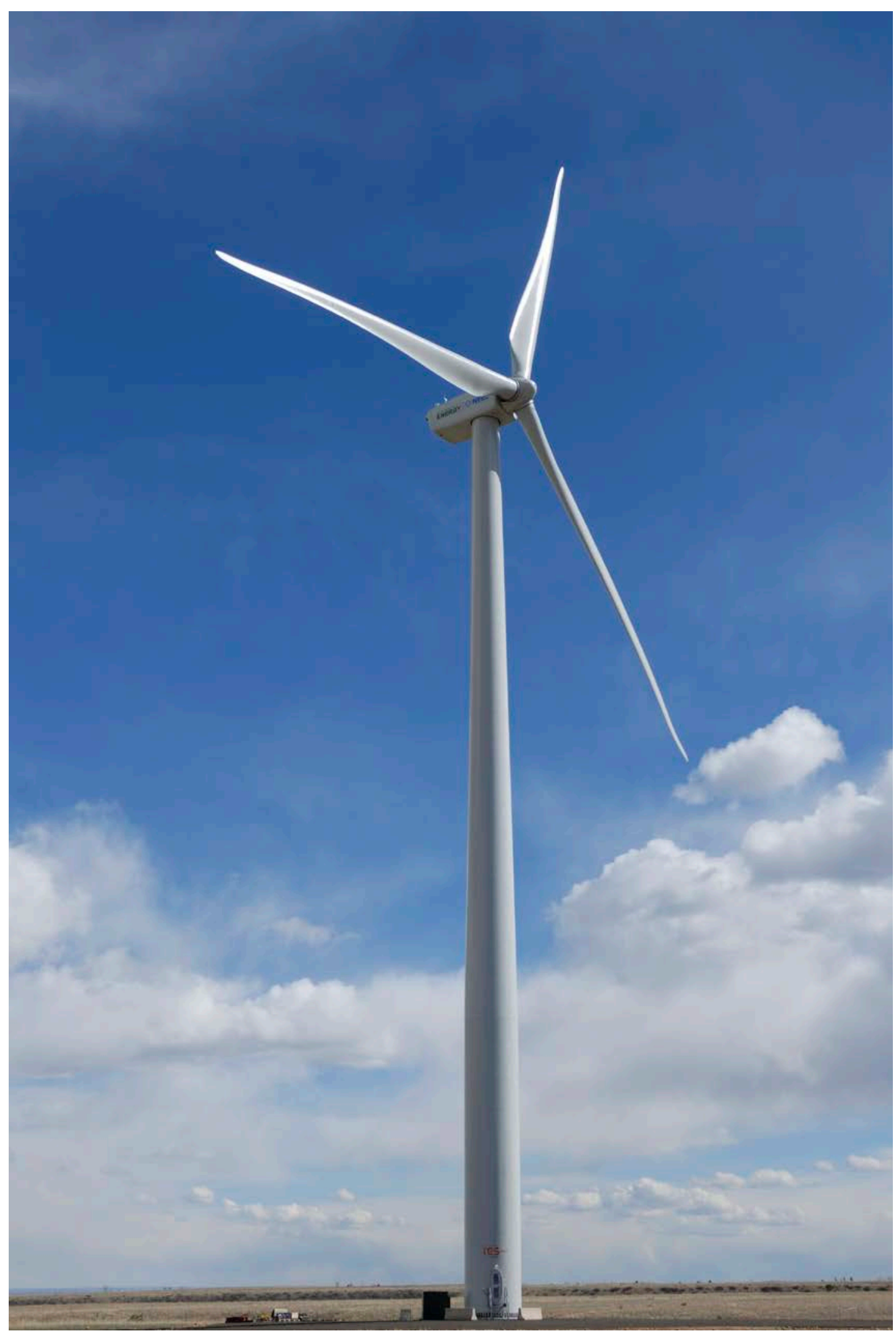

Figure 1. DOE 1.5 at the NWTC. Photo by Jeroen van Dam, NREL 


\section{Test Site Description}

The test turbine was located at Site 4.0 at the NWTC. The turbine provided power to the NWTC 10-MW utility power grid through a $0.690 / 13.2-\mathrm{kV}$ transformer rated at 1,750 $\mathrm{kVA}$. Figure 2 shows the electrical site diagram, which indicates the placement of NREL's power quality instrumentation. Wind speed information was measured at hub height from the turbine meteorological tower 2.1 rotor diameters upstream, which is in compliance with the requirements from the Standard.

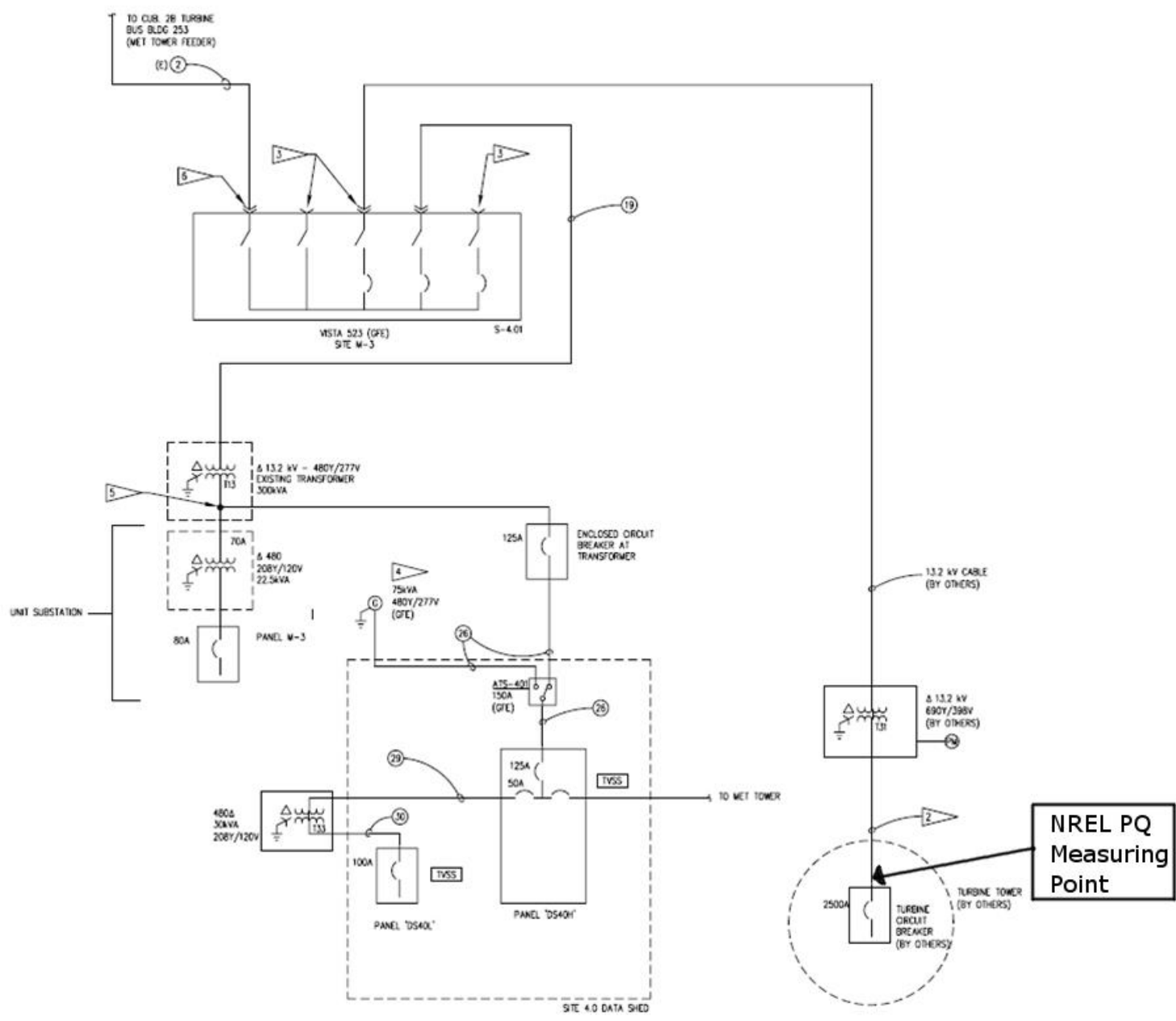

Figure 2. Site electrical diagram 


\section{Continuous Operation Test Results}

\subsection{Active and Reactive Power, Power Factor}

The relationship between active and reactive power was measured at the wind turbine low voltage $(0.690 \mathrm{kV})$ terminals. Time series measurements of voltage, current, and wind speed were taken during continuous operation. Using these data, 10-minute bin average statistics were calculated for each $1 \mathrm{~m} / \mathrm{s}$ wind speed (in accordance with the Standard). Table 5 and Figure 3 show these results. The power factor (Figure 4) was calculated using active and reactive power values. Figure 5 shows the reactive power demand. Figure 6 illustrates the turbulence intensity observed during the testing period. Note that the active power curve shown in Figure 3 cannot be used for the DOE 1.5 power performance evaluation. The official power curve will be published in the DOE 1.5 power performance test report.

Table 5. Number of Data Points per 1-m/s Wind Speed Bins

\begin{tabular}{|c|c|}
\hline $\begin{array}{c}\text { Wind Speed Bin, } \\
\text { m/s }\end{array}$ & $\begin{array}{c}\text { Number of Valid 10-Min Data } \\
\text { Points }\end{array}$ \\
\hline 0 to 1 & 0 \\
\hline 1 to 2 & 0 \\
\hline 2 to 3 & 8 \\
\hline 3 to 4 & 81 \\
\hline 4 to 5 & 92 \\
\hline 5 to 6 & 106 \\
\hline 6 to 7 & 92 \\
\hline 7 to 8 & 75 \\
\hline 8 to 9 & 64 \\
\hline 9 to 10 & 65 \\
\hline 10 to 11 & 44 \\
\hline 11 to 12 & 47 \\
\hline 12 to 13 & 23 \\
\hline 13 to 14 & 16 \\
\hline 14 to 15 & 5 \\
\hline 15 to 16 & 5 \\
\hline 16 to 17 & 4 \\
\hline 17 to 18 & 3 \\
\hline & \\
\hline
\end{tabular}




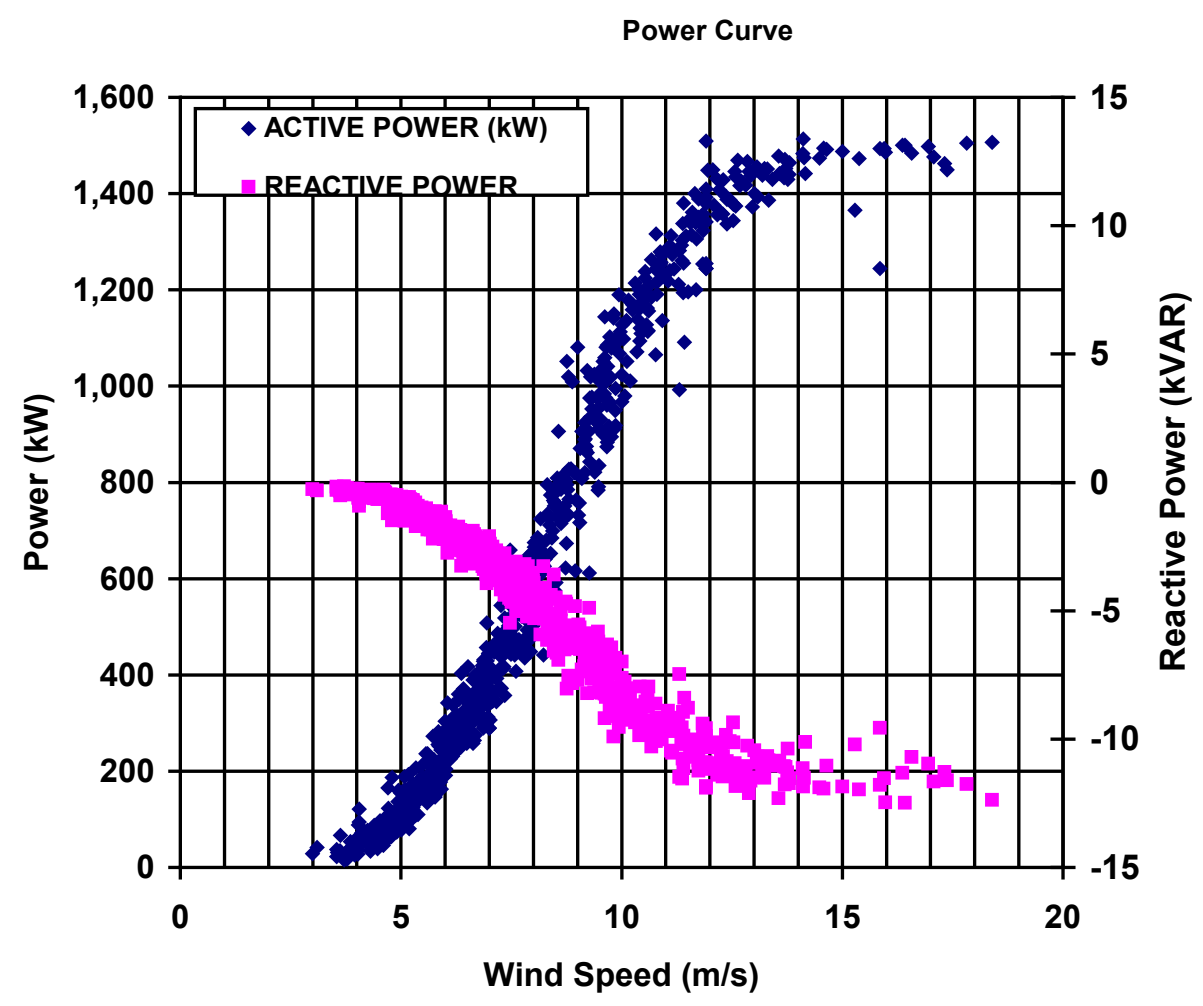

Figure 3. Active and reactive power versus wind speed

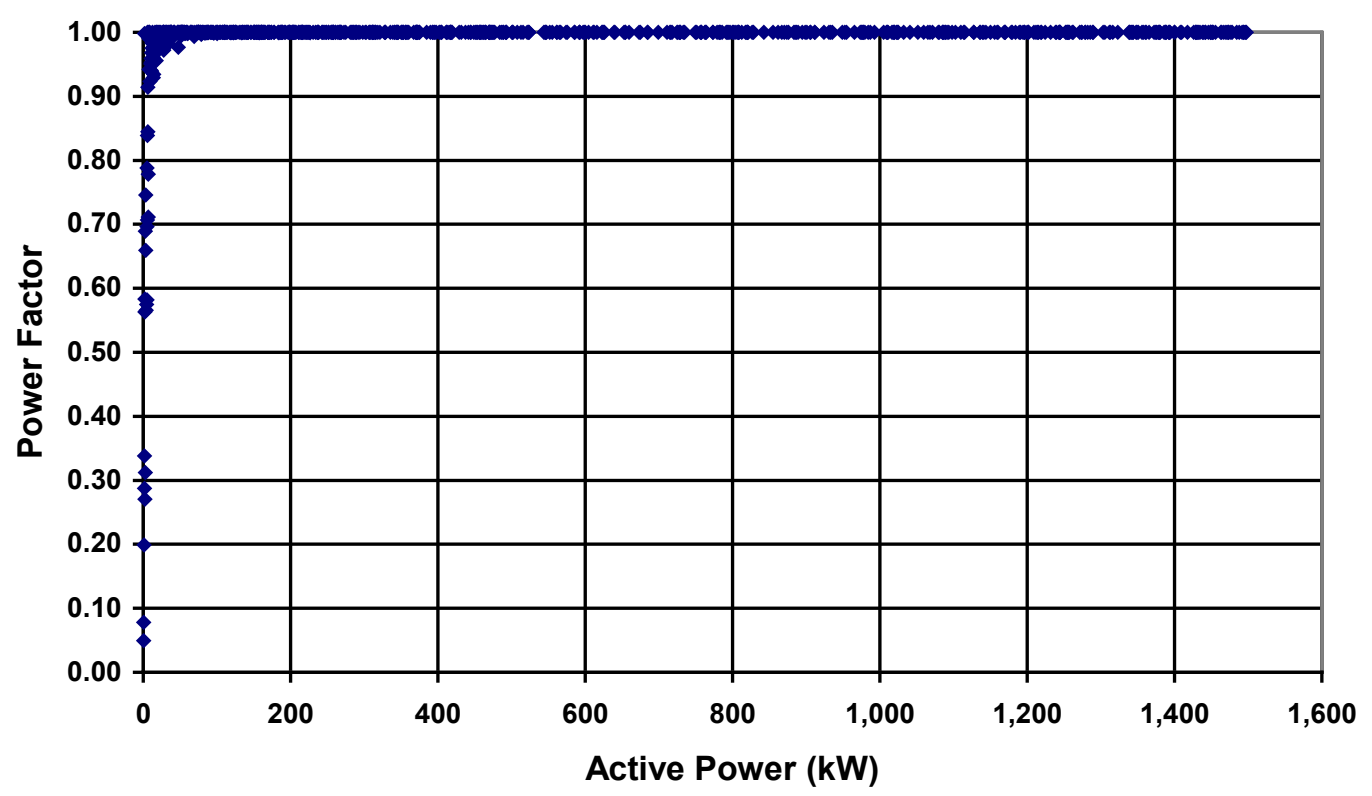

Figure 4. Power factor versus active power 


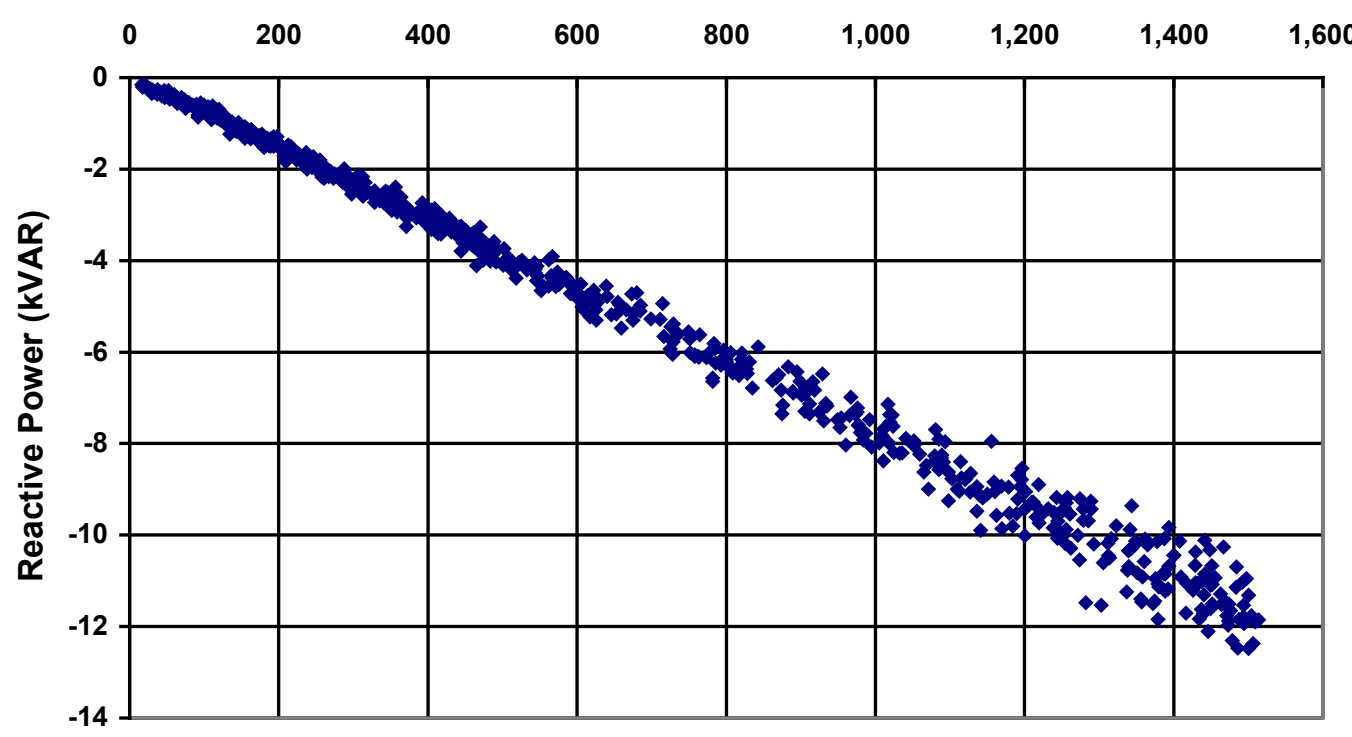

Active power (kW)

Figure 5. Reactive power versus active power

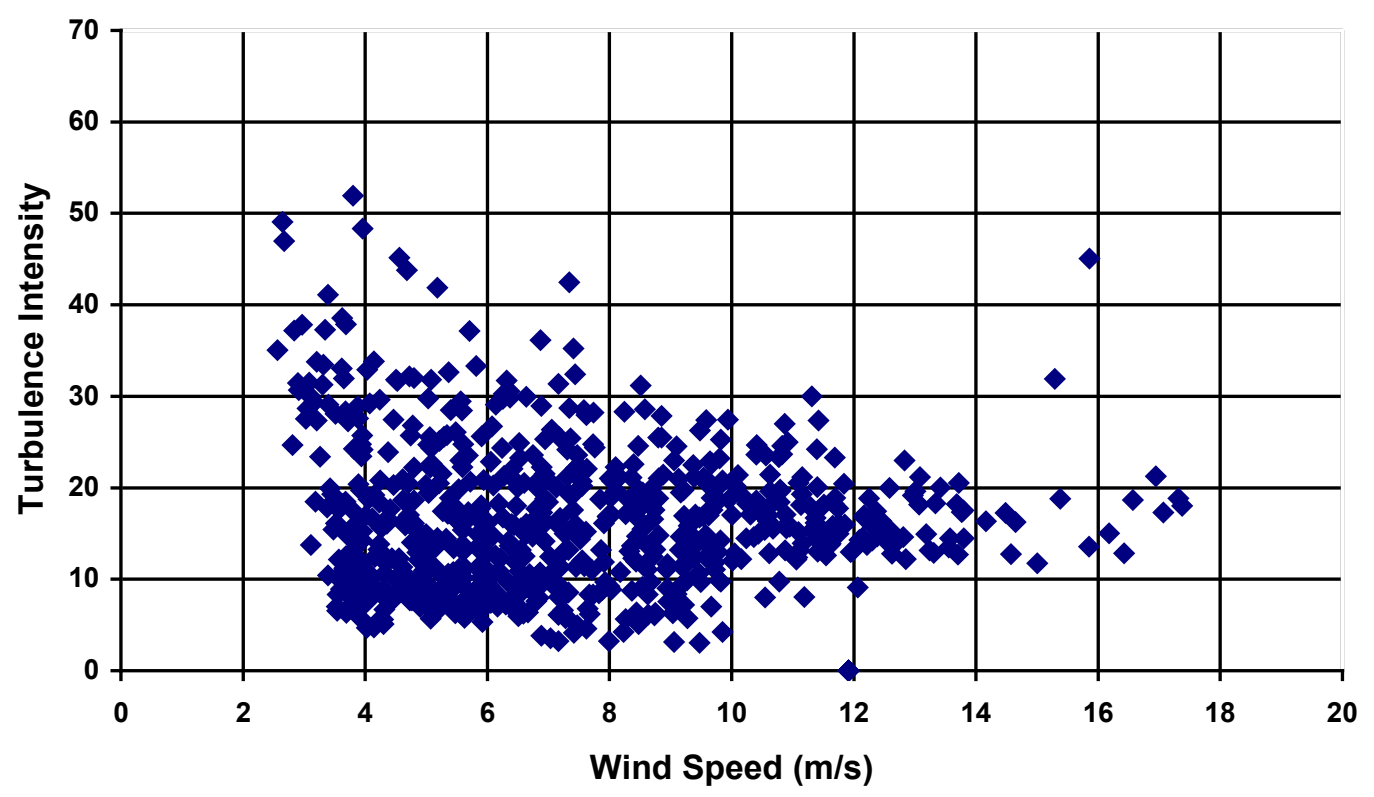

Figure 6. Turbulence intensity versus wind speed 
The 10-minute reactive power average data were sorted by active power according to the method of bins and are shown in Table 6 . The maximum active power statistics were taken from the 600 seconds $\left(\mathrm{P}_{600}\right), 60$ seconds $\left(P_{60}\right)$, and 0.2 seconds $\left(P_{0.2}\right)$ values (Table 7). The reactive power at peak power $\left(P_{m c}\right), \mathrm{P}_{600}, P_{60}$, and $P_{0.2}$ were determined by extrapolating the relation between the active and reactive power $\left(\mathrm{Q}_{\mathrm{mc}}\right)$ (shown in Table 7).

Table 6. Data Binned by Real Power

\begin{tabular}{|c|c|c|c|}
\hline $\begin{array}{c}\text { Power Bin } \\
\text { (\% of rated power) }\end{array}$ & $\begin{array}{c}\text { Number of } 10-\text { Minute } \\
\text { Data Points Per Bin }\end{array}$ & $\begin{array}{c}\text { Output Power, } \\
\text { Bin-Mean-Value }(\mathrm{kW})\end{array}$ & $\begin{array}{c}\text { Reactive Power, } \\
\text { Bin-Mean-Value (kVAR) }\end{array}$ \\
\hline-5 to 5 & 140 & 30.25 & -2.44 \\
\hline 5 to 15 & 149 & 143.33 & -1.53 \\
\hline 15 to 25 & 92 & 301.61 & -2.59 \\
\hline 25 to 35 & 66 & 452.99 & -3.78 \\
\hline 35 to 45 & 36 & 600.72 & -4.78 \\
\hline 45 to 55 & 46 & 766.90 & -6.20 \\
\hline 55 to 65 & 29 & 899.74 & -7.12 \\
\hline 65 to 75 & 40 & $1,043.41$ & -8.07 \\
\hline 75 to 85 & 51 & $1,206.13$ & -9.41 \\
\hline 85 to 95 & 45 & $1,352.76$ & -10.51 \\
\hline 95 to 105 & 35 & $1,458.81$ & -11.22 \\
\hline 105 to 115 & 0 & 0.00 & 0.00 \\
\hline
\end{tabular}

Table 7. Maximum Instantaneous Real and Reactive Power

\begin{tabular}{|c|c|c|c|c|c|c|c|}
\hline \multicolumn{2}{|c|}{$\begin{array}{l}\text { Max. Permitted Power, } \\
P_{m c}\end{array}$} & \multicolumn{2}{|c|}{ 600-Sec Average } & \multicolumn{2}{|c|}{ 60-Sec Average } & \multicolumn{2}{|c|}{$0.2-S e c$ Average } \\
\hline $\begin{array}{c}P_{m c}, k W \\
\mathbf{1 , 5 4 5}\end{array}$ & $\begin{array}{c}p_{m c}=P_{m d} / P_{n} \\
1.03\end{array}$ & $\begin{array}{l}P_{m c}, k W \\
\mathbf{1 , 4 9 7 . 6 9}\end{array}$ & $\begin{array}{c}p_{m c}=P_{m d} / P_{n} \\
0.998\end{array}$ & $\begin{array}{l}P_{60}, \mathrm{~kW} \\
\mathbf{1 , 6 2 8 . 3 4}\end{array}$ & $\begin{array}{c}p_{60}=P_{60} / P_{n} \\
1.09\end{array}$ & $\begin{array}{l}P_{0.2}, \mathrm{~kW} \\
\mathbf{1 , 8 7 7 . 5 7}\end{array}$ & $\begin{array}{c}p_{0.2}=P_{0.2} / P_{n} \\
1.25\end{array}$ \\
\hline $\begin{array}{c}Q_{m c} \text { at } P_{m c} \\
k V A R \\
\mathbf{- 1 1 . 7 4}\end{array}$ & $\begin{aligned} q_{m c} & =Q_{m d} P_{n} \\
& -0.01\end{aligned}$ & $\begin{array}{c}Q_{m c} \text { at } \\
P_{m c}, k V A R \\
\mathbf{- 1 1 . 4 6}\end{array}$ & $\begin{array}{c}q_{m c}=Q_{m d} / P_{n} \\
-0.01\end{array}$ & $\begin{array}{c}Q_{60} \text { at } P_{60}, \\
k V A R \\
\mathbf{- 1 2 . 1 9}\end{array}$ & $\begin{array}{c}q_{60}=Q_{60} / P_{n} \\
-\mathbf{0 . 0 1}\end{array}$ & $\begin{array}{c}Q_{0.2} \text { at } P_{0.2}, \\
k V A R \\
-\mathbf{- 1 3 . 2 3}\end{array}$ & $\begin{array}{c}q_{0.2}=Q_{0.2} / P_{r} \\
\quad \mathbf{0 . 0 1}\end{array}$ \\
\hline
\end{tabular}

Notes: Data were not normalized to sea-level density. NREL's site average air density is $1.0 \mathrm{~kg} / \mathrm{m}^{3}$ The active power curve shown in Figure 3 could not be used for the DOE 1.5 power performance evaluation. The official power curve will be published in the DOE 1.5 power performance test report.

\subsection{Line Voltage Distortions}

The average voltage total harmonic distortions (THD) calculated during the continuous operation test for each phase were:

- Phase A - $1.202 \%$

- Phase B-1.186\%

- Phase $\mathrm{C}-1.162 \%$. 
The maximum voltage THDs calculated during the test for each phase were:

- $\quad$ Phase A - $1.870 \%$

- $\quad$ Phase B - $1.828 \%$

- Phase C $-1.863 \%$.

Prior to starting the test we verified that the grid voltage THD conditions were less than $5 \%$ at the voltage terminals, whereas the turbine was not generating. All voltage THDs were calculated from collected harmonic voltage time series data. The harmonic voltages were subgrouped according to Section 5.6 of IEC 61000-4-7/CDV: General Guide on Harmonics and Interharmonics Measurements and Instrumentation [2]. The window width used during measurements was $T_{w}=12$.

\subsection{Current Harmonics}

The individual current harmonics were measured during continuous operation. From these, 10-minute statistics were calculated for each harmonic order (up to $50^{\text {th }}$ ) at the given output power, finally determining the maximum individual current harmonic. Table 8 shows the harmonic data and the maximum current total demand distortion (TDD) values as a percentage of nominal current $\left(I_{n}\right)$. Figure 7 shows 10-minute average data for maximum current TDD ( $\%$ of $\left.I_{n}\right)$ of the three phases as a function of output power. The IEEE 519-1992: Harmonic Limits [3] sets a 5\% limit on current TDD for all power generation equipment. 
Table 8. Maximum Current Harmonics (10-Minute Averages)

\begin{tabular}{|c|c|c|c|c|c|c|c|c|c|c|c|}
\hline $\mathrm{P}_{\text {bin }}(\%)$ & 0 & 10 & 20 & 30 & 40 & 50 & 60 & 70 & 80 & 90 & 100 \\
\hline $\mathrm{H}$ & $I_{h}(\%)$ & $I_{h}(\%)$ & $\ln (\%)$ & $I_{h}(\%)$ & $I_{h}(\%)$ & $I_{h}(\%)$ & $I_{h}(\%)$ & $I_{h}(\%)$ & $I_{h}(\%)$ & $I_{h}(\%)$ & $I_{h}(\%)$ \\
\hline 1 & 4.77 & 12.58 & 21.00 & 29.17 & 37.18 & 45.18 & 53.79 & 60.85 & 69.69 & 77.51 & 81.65 \\
\hline 2 & 0.11 & 0.12 & 0.11 & 0.14 & 0.15 & 0.14 & 0.16 & 0.16 & 0.18 & 0.18 & 0.19 \\
\hline 3 & 0.72 & 0.70 & 0.63 & 0.62 & 0.62 & 0.60 & 0.64 & 0.65 & 0.66 & 0.65 & 0.64 \\
\hline 4 & 0.14 & 0.16 & 0.14 & 0.15 & 0.16 & 0.17 & 0.18 & 0.18 & 0.18 & 0.17 & 0.19 \\
\hline 5 & 2.04 & 2.19 & 1.77 & 1.70 & 1.64 & 1.77 & 1.89 & 1.68 & 1.85 & 1.66 & 1.66 \\
\hline 6 & 0.12 & 0.14 & 0.15 & 0.17 & 0.17 & 0.18 & 0.19 & 0.20 & 0.23 & 0.24 & 0.26 \\
\hline 7 & 1.52 & 1.74 & 1.82 & 1.84 & 1.81 & 1.35 & 2.05 & 1.44 & 1.90 & 1.46 & 1.48 \\
\hline 8 & 0.12 & 0.13 & 0.14 & 0.14 & 0.15 & 0.11 & 0.16 & 0.12 & 0.15 & 0.13 & 0.14 \\
\hline 9 & 0.13 & 0.15 & 0.15 & 0.14 & 0.14 & 0.13 & 0.14 & 0.13 & 0.14 & 0.15 & 0.15 \\
\hline 10 & 0.08 & 0.08 & 0.08 & 0.08 & 0.08 & 0.09 & 0.09 & 0.09 & 0.09 & 0.09 & 0.09 \\
\hline 11 & 0.27 & 0.34 & 0.37 & 0.43 & 0.43 & 0.47 & 0.51 & 0.47 & 0.47 & 0.47 & 0.46 \\
\hline 12 & 0.08 & 0.08 & 0.08 & 0.08 & 0.08 & 0.08 & 0.08 & 0.08 & 0.08 & 0.08 & 0.08 \\
\hline 13 & 0.10 & 0.12 & 0.14 & 0.17 & 0.25 & 0.26 & 0.27 & 0.32 & 0.31 & 0.32 & 0.35 \\
\hline 14 & 0.07 & 0.07 & 0.07 & 0.07 & 0.07 & 0.07 & 0.07 & 0.07 & 0.06 & 0.06 & 0.06 \\
\hline 15 & 0.08 & 0.08 & 0.08 & 0.08 & 0.07 & 0.07 & 0.07 & 0.07 & 0.07 & 0.07 & 0.07 \\
\hline 16 & 0.08 & 0.09 & 0.09 & 0.09 & 0.09 & 0.09 & 0.09 & 0.09 & 0.08 & 0.08 & 0.08 \\
\hline 17 & 0.24 & 0.26 & 0.24 & 0.24 & 0.25 & 0.20 & 0.20 & 0.20 & 0.18 & 0.18 & 0.23 \\
\hline 18 & 0.14 & 0.16 & 0.14 & 0.14 & 0.14 & 0.15 & 0.14 & 0.15 & 0.14 & 0.14 & 0.14 \\
\hline 19 & 0.33 & 0.35 & 0.30 & 0.30 & 0.27 & 0.25 & 0.25 & 0.26 & 0.25 & 0.27 & 0.30 \\
\hline 20 & 0.17 & 0.22 & 0.19 & 0.19 & 0.20 & 0.21 & 0.20 & 0.21 & 0.21 & 0.21 & 0.21 \\
\hline 21 & 0.17 & 0.24 & 0.19 & 0.20 & 0.20 & 0.22 & 0.21 & 0.22 & 0.22 & 0.22 & 0.22 \\
\hline 22 & 0.17 & 0.23 & 0.20 & 0.19 & 0.20 & 0.20 & 0.20 & 0.21 & 0.21 & 0.22 & 0.22 \\
\hline $\mathrm{P}_{\text {bin }}(\%)$ & 0 & 10 & 20 & 30 & 40 & 50 & 60 & 70 & 80 & 90 & 100 \\
\hline $\mathrm{H}$ & $I_{h}(\%)$ & $\mathrm{I}_{\mathrm{h}}(\%)$ & $I_{h}(\%)$ & $\mathrm{I}_{\mathrm{h}}(\%)$ & $I_{h}(\%)$ & $I_{h}(\%)$ & $I_{h}(\%)$ & $I_{h}(\%)$ & $I_{h}(\%)$ & $I_{h}(\%)$ & $I_{h}(\%)$ \\
\hline 23 & 0.55 & 0.62 & 0.63 & 0.63 & 0.63 & 0.67 & 0.68 & 0.71 & 0.71 & 0.75 & 0.74 \\
\hline 24 & 0.13 & 0.16 & 0.14 & 0.14 & 0.14 & 0.14 & 0.14 & 0.15 & 0.15 & 0.16 & 0.16 \\
\hline 25 & 0.22 & 0.26 & 0.23 & 0.22 & 0.22 & 0.20 & 0.18 & 0.18 & 0.16 & 0.17 & 0.16 \\
\hline 26 & 0.09 & 0.10 & 0.10 & 0.09 & 0.09 & 0.09 & 0.09 & 0.09 & 0.09 & 0.09 & 0.09 \\
\hline 27 & 0.08 & 0.10 & 0.09 & 0.09 & 0.09 & 0.09 & 0.09 & 0.09 & 0.09 & 0.09 & 0.09 \\
\hline 28 & 0.08 & 0.09 & 0.09 & 0.09 & 0.08 & 0.09 & 0.08 & 0.09 & 0.09 & 0.09 & 0.09 \\
\hline 29 & 0.11 & 0.16 & 0.15 & 0.16 & 0.21 & 0.22 & 0.23 & 0.27 & 0.27 & 0.27 & 0.28 \\
\hline 30 & 0.19 & 0.19 & 0.11 & 0.12 & 0.10 & 0.10 & 0.11 & 0.11 & 0.13 & 0.12 & 0.14 \\
\hline 31 & 0.07 & 0.10 & 0.08 & 0.09 & 0.09 & 0.07 & 0.08 & 0.08 & 0.07 & 0.08 & 0.08 \\
\hline 32 & 0.24 & 0.25 & 0.13 & 0.12 & 0.08 & 0.07 & 0.07 & 0.07 & 0.07 & 0.07 & 0.08 \\
\hline 33 & 0.05 & 0.06 & 0.06 & 0.06 & 0.05 & 0.05 & 0.05 & 0.05 & 0.05 & 0.05 & 0.06 \\
\hline 34 & 0.04 & 0.04 & 0.05 & 0.05 & 0.04 & 0.04 & 0.04 & 0.04 & 0.04 & 0.04 & 0.04 \\
\hline 35 & 0.09 & 0.09 & 0.10 & 0.10 & 0.09 & 0.08 & 0.08 & 0.08 & 0.07 & 0.07 & 0.08 \\
\hline 36 & 0.03 & 0.03 & 0.03 & 0.03 & 0.03 & 0.03 & 0.03 & 0.03 & 0.03 & 0.03 & 0.03 \\
\hline 37 & 0.05 & 0.04 & 0.05 & 0.05 & 0.04 & 0.04 & 0.03 & 0.03 & 0.03 & 0.03 & 0.04 \\
\hline 38 & 0.02 & 0.02 & 0.02 & 0.02 & 0.02 & 0.02 & 0.02 & 0.02 & 0.02 & 0.02 & 0.02 \\
\hline 39 & 0.02 & 0.02 & 0.02 & 0.02 & 0.02 & 0.02 & 0.02 & 0.02 & 0.02 & 0.02 & 0.02 \\
\hline 40 & 0.01 & 0.02 & 0.02 & 0.01 & 0.01 & 0.02 & 0.02 & 0.02 & 0.02 & 0.02 & 0.02 \\
\hline 41 & 0.03 & 0.04 & 0.04 & 0.04 & 0.04 & 0.05 & 0.04 & 0.05 & 0.05 & 0.05 & 0.04 \\
\hline 42 & 0.01 & 0.01 & 0.01 & 0.01 & 0.01 & 0.01 & 0.01 & 0.01 & 0.01 & 0.01 & 0.01 \\
\hline 43 & 0.02 & 0.02 & 0.02 & 0.02 & 0.02 & 0.02 & 0.02 & 0.02 & 0.02 & 0.02 & 0.02 \\
\hline 44 & 0.02 & 0.02 & 0.02 & 0.02 & 0.02 & 0.02 & 0.02 & 0.02 & 0.02 & 0.02 & 0.02 \\
\hline 45 & 0.02 & 0.02 & 0.02 & 0.02 & 0.02 & 0.02 & 0.02 & 0.02 & 0.02 & 0.02 & 0.02 \\
\hline 46 & 0.02 & 0.02 & 0.02 & 0.02 & 0.02 & 0.02 & 0.02 & 0.02 & 0.02 & 0.02 & 0.02 \\
\hline 47 & 0.01 & 0.02 & 0.02 & 0.02 & 0.02 & 0.02 & 0.01 & 0.02 & 0.01 & 0.01 & 0.01 \\
\hline 48 & 0.01 & 0.01 & 0.01 & 0.01 & 0.01 & 0.01 & 0.01 & 0.01 & 0.01 & 0.01 & 0.01 \\
\hline 49 & 0.01 & 0.01 & 0.01 & 0.01 & 0.01 & 0.01 & 0.01 & 0.01 & 0.01 & 0.01 & 0.01 \\
\hline 50 & 0.02 & 0.02 & 0.02 & 0.02 & 0.02 & 0.02 & 0.02 & 0.02 & 0.02 & 0.02 & 0.02 \\
\hline THC (\%) & 0.35 & 0.91 & 1.51 & 2.09 & 2.67 & 3.24 & 3.86 & 4.37 & 5.00 & 5.56 & 5.86 \\
\hline
\end{tabular}

\begin{tabular}{|l|l|l|c|}
\hline Max. phase A current TDD (\% of $I_{n}$ ) & 2.82 & Output power at max. current THD (kW) & 866.83 \\
\hline Max. phase B current TDD (\% of $I_{n}$ ) & 2.67 & Output power at max. current THD (kW) & 866.83 \\
\hline Max. phase C current TDD (\% of $I_{n}$ ) & 2.70 & Output power at max. current THD (kW) & 866.83 \\
\hline
\end{tabular}


The current harmonics were subgrouped according to Section 5.6 of IEC 61000-4-7/CDV [2] as prescribed in the Standard. The window width used during measurements was $T_{w}=12$.

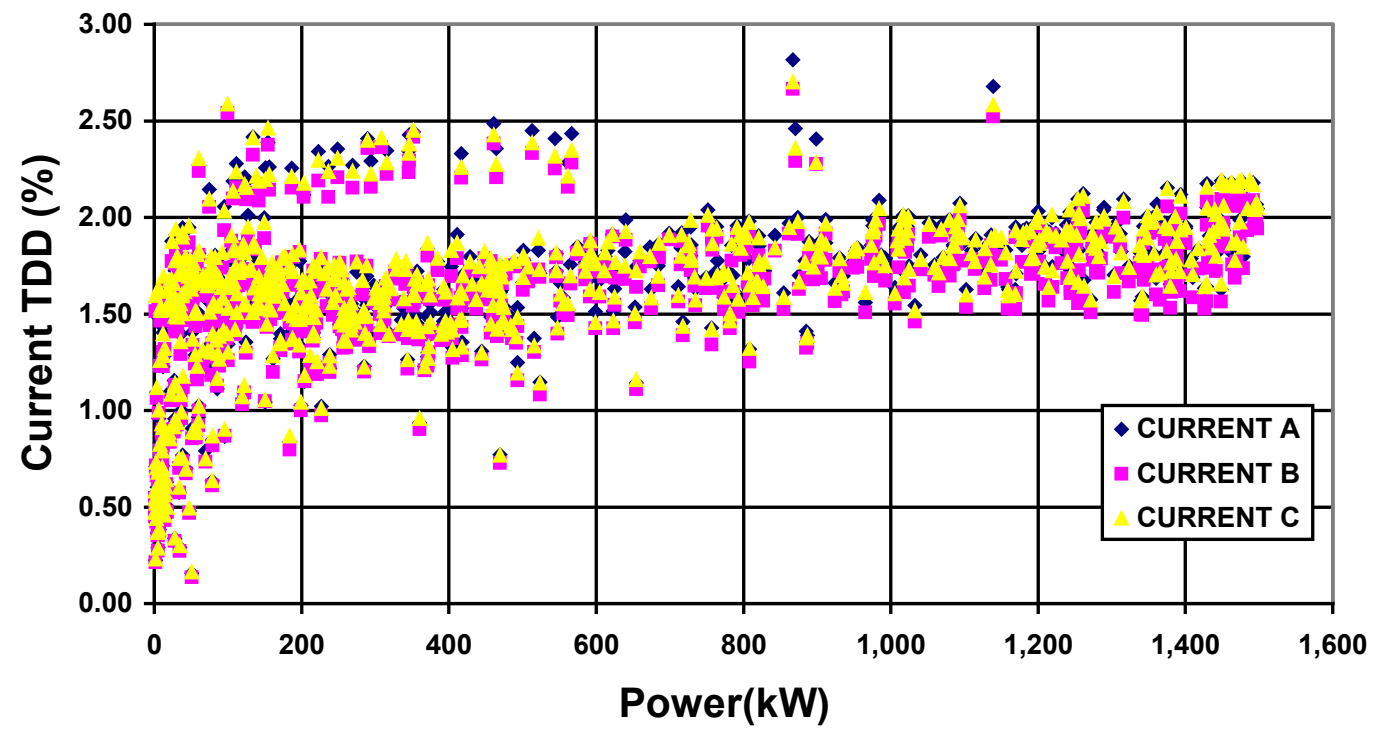

Figure 7. Current TDD versus active power

\subsection{Current Interharmonics}

Table 9 lists the maximum 10-minute average for each individual interharmonic current below $2 \mathrm{kHz}$ as a percentage of nominal current $\left(I_{n}\right)$. 
Table 9. Current Interharmonics

\begin{tabular}{|c|c|c|c|c|c|c|c|c|c|c|c|}
\hline$f$ & 0 & 10 & 20 & 30 & 40 & 50 & 60 & 70 & 80 & 90 & 100 \\
\hline$(\mathrm{Hz})$ & $I_{h}(\%)$ & $I_{h}(\%)$ & $I_{h}(\%)$ & $I_{h}(\%)$ & $I_{h}(\%)$ & $I_{h}(\%)$ & $I_{h}(\%)$ & $I_{h}(\%)$ & $I_{h}(\%)$ & $I_{h}(\%)$ & $I_{h}(\%)$ \\
\hline 90 & 0.14 & 0.16 & 0.20 & 0.25 & 0.24 & 0.32 & 0.37 & 0.44 & 0.33 & 0.47 & 0.40 \\
\hline 150 & 0.20 & 0.23 & 0.22 & 0.23 & 0.31 & 0.33 & 0.35 & 0.36 & 0.36 & 0.38 & 0.40 \\
\hline 210 & 0.24 & 0.29 & 0.28 & 0.35 & 0.36 & 0.36 & 0.36 & 0.36 & 0.34 & 0.32 & 0.32 \\
\hline 270 & 0.19 & 0.23 & 0.24 & 0.25 & 0.31 & 0.28 & 0.28 & 0.36 & 0.31 & 0.43 & 0.58 \\
\hline 330 & 0.22 & 0.26 & 0.27 & 0.31 & 0.32 & 0.31 & 0.31 & 0.30 & 0.29 & 0.30 & 0.29 \\
\hline 390 & 0.23 & 0.26 & 0.28 & 0.30 & 0.33 & 0.35 & 0.39 & 0.41 & 0.46 & 0.48 & 0.51 \\
\hline 450 & 0.22 & 0.25 & 0.27 & 0.28 & 0.28 & 0.21 & 0.29 & 0.20 & 0.29 & 0.20 & 0.21 \\
\hline 510 & 0.19 & 0.20 & 0.22 & 0.23 & 0.24 & 0.20 & 0.28 & 0.23 & 0.30 & 0.25 & 0.25 \\
\hline 570 & 0.15 & 0.15 & 0.16 & 0.16 & 0.16 & 0.16 & 0.16 & 0.17 & 0.17 & 0.17 & 0.17 \\
\hline 630 & 0.13 & 0.14 & 0.15 & 0.15 & 0.15 & 0.15 & 0.15 & 0.16 & 0.16 & 0.16 & 0.16 \\
\hline 690 & 0.13 & 0.14 & 0.14 & 0.14 & 0.14 & 0.15 & 0.15 & 0.15 & 0.15 & 0.15 & 0.15 \\
\hline 750 & 0.13 & 0.13 & 0.13 & 0.13 & 0.13 & 0.13 & 0.13 & 0.13 & 0.13 & 0.13 & 0.14 \\
\hline 810 & 0.12 & 0.12 & 0.13 & 0.13 & 0.12 & 0.12 & 0.12 & 0.12 & 0.12 & 0.12 & 0.12 \\
\hline 870 & 0.12 & 0.12 & 0.13 & 0.13 & 0.13 & 0.12 & 0.12 & 0.12 & 0.12 & 0.12 & 0.12 \\
\hline 930 & 0.14 & 0.14 & 0.15 & 0.15 & 0.14 & 0.14 & 0.14 & 0.14 & 0.13 & 0.13 & 0.13 \\
\hline 990 & 0.17 & 0.20 & 0.19 & 0.18 & 0.18 & 0.17 & 0.17 & 0.17 & 0.17 & 0.16 & 0.17 \\
\hline 1050 & 0.22 & 0.26 & 0.23 & 0.22 & 0.22 & 0.23 & 0.22 & 0.23 & 0.22 & 0.22 & 0.22 \\
\hline 1110 & 0.26 & 0.33 & 0.27 & 0.27 & 0.28 & 0.30 & 0.29 & 0.30 & 0.29 & 0.30 & 0.29 \\
\hline 1170 & 0.28 & 0.37 & 0.31 & 0.32 & 0.33 & 0.35 & 0.34 & 0.35 & 0.34 & 0.35 & 0.35 \\
\hline 1230 & 0.29 & 0.40 & 0.33 & 0.34 & 0.35 & 0.37 & 0.37 & 0.39 & 0.38 & 0.38 & 0.39 \\
\hline 1290 & 0.30 & 0.42 & 0.35 & 0.35 & 0.37 & 0.38 & 0.38 & 0.39 & 0.40 & 0.40 & 0.40 \\
\hline 1350 & 0.29 & 0.38 & 0.34 & 0.33 & 0.36 & 0.34 & 0.35 & 0.37 & 0.36 & 0.37 & 0.37 \\
\hline 1410 & 0.25 & 0.32 & 0.28 & 0.28 & 0.29 & 0.30 & 0.29 & 0.33 & 0.31 & 0.32 & 0.32 \\
\hline 1470 & 0.20 & 0.25 & 0.22 & 0.23 & 0.23 & 0.22 & 0.23 & 0.23 & 0.23 & 0.23 & 0.25 \\
\hline 1530 & 0.17 & 0.20 & 0.18 & 0.19 & 0.18 & 0.17 & 0.17 & 0.17 & 0.17 & 0.17 & 0.19 \\
\hline 1590 & 0.14 & 0.18 & 0.15 & 0.15 & 0.15 & 0.16 & 0.15 & 0.16 & 0.16 & 0.16 & 0.16 \\
\hline 1650 & 0.14 & 0.17 & 0.16 & 0.16 & 0.15 & 0.16 & 0.15 & 0.17 & 0.17 & 0.17 & 0.17 \\
\hline 1710 & 0.14 & 0.17 & 0.15 & 0.15 & 0.14 & 0.15 & 0.15 & 0.15 & 0.15 & 0.15 & 0.15 \\
\hline 1770 & 0.13 & 0.16 & 0.14 & 0.14 & 0.13 & 0.13 & 0.14 & 0.14 & 0.14 & 0.14 & 0.14 \\
\hline 1830 & 0.12 & 0.15 & 0.14 & 0.15 & 0.17 & 0.17 & 0.17 & 0.17 & 0.17 & 0.18 & 0.17 \\
\hline 1890 & 0.25 & 0.26 & 0.18 & 0.17 & 0.15 & 0.13 & 0.14 & 0.13 & 0.14 & 0.14 & 0.15 \\
\hline 1950 & 0.10 & 0.12 & 0.11 & 0.11 & 0.11 & 0.11 & 0.11 & 0.10 & 0.11 & 0.11 & 0.11 \\
\hline 2010 & 0.15 & 0.15 & 0.11 & 0.12 & 0.12 & 0.13 & 0.13 & 0.14 & 0.14 & 0.15 & 0.15 \\
\hline 2070 & 0.07 & 0.07 & 0.07 & 0.07 & 0.06 & 0.06 & 0.06 & 0.06 & 0.06 & 0.07 & 0.07 \\
\hline 2130 & 0.05 & 0.06 & 0.06 & 0.06 & 0.06 & 0.06 & 0.06 & 0.06 & 0.06 & 0.06 & 0.06 \\
\hline 2190 & 0.04 & 0.05 & 0.05 & 0.05 & 0.05 & 0.05 & 0.05 & 0.05 & 0.05 & 0.05 & 0.05 \\
\hline 2250 & 0.07 & 0.07 & 0.07 & 0.07 & 0.06 & 0.06 & 0.06 & 0.06 & 0.06 & 0.06 & 0.06 \\
\hline 2310 & 0.03 & 0.04 & 0.03 & 0.03 & 0.03 & 0.04 & 0.04 & 0.04 & 0.04 & 0.04 & 0.04 \\
\hline 2370 & 0.05 & 0.05 & 0.04 & 0.04 & 0.04 & 0.04 & 0.04 & 0.04 & 0.04 & 0.04 & 0.04 \\
\hline 2430 & 0.02 & 0.03 & 0.03 & 0.03 & 0.03 & 0.03 & 0.03 & 0.03 & 0.03 & 0.03 & 0.03 \\
\hline 2490 & 0.02 & 0.02 & 0.02 & 0.02 & 0.02 & 0.02 & 0.02 & 0.02 & 0.02 & 0.02 & 0.03 \\
\hline 2550 & 0.02 & 0.02 & 0.02 & 0.02 & 0.02 & 0.02 & 0.02 & 0.02 & 0.02 & 0.02 & 0.02 \\
\hline 2610 & 0.26 & 0.26 & 0.26 & 0.26 & 0.26 & 0.26 & 0.26 & 0.26 & 0.26 & 0.26 & 0.26 \\
\hline 2670 & 0.02 & 0.08 & 0.08 & 0.08 & 0.08 & 0.08 & 0.06 & 0.07 & 0.07 & 0.04 & 0.03 \\
\hline 2730 & 0.31 & 0.31 & 0.31 & 0.31 & 0.31 & 0.32 & 0.32 & 0.31 & 0.31 & 0.31 & 0.31 \\
\hline 2790 & 0.02 & 0.09 & 0.09 & 0.09 & 0.09 & 0.09 & 0.07 & 0.09 & 0.09 & 0.04 & 0.02 \\
\hline 2850 & 0.02 & 0.02 & 0.02 & 0.02 & 0.02 & 0.02 & 0.02 & 0.02 & 0.02 & 0.02 & 0.02 \\
\hline 2910 & 0.01 & 0.02 & 0.02 & 0.02 & 0.01 & 0.02 & 0.02 & 0.02 & 0.02 & 0.02 & 0.02 \\
\hline 2970 & 0.24 & 0.24 & 0.24 & 0.24 & 0.24 & 0.24 & 0.25 & 0.24 & 0.24 & 0.24 & 0.24 \\
\hline 3030 & 0.02 & 0.07 & 0.07 & 0.07 & 0.07 & 0.07 & 0.05 & 0.06 & 0.06 & 0.03 & 0.02 \\
\hline
\end{tabular}


The current interharmonics were subgrouped according to Annex A of IEC 61000-47/CDV: General Guide on Harmonics and Interharmonics Measurements and Instrumentation [2], as prescribed in the Standard. The window width used during measurements was $T_{w}=12$.

\subsection{Current Distortions}

Table 10 lists the maximum 10-minute average current distortions in the range of $2 \mathrm{kHz}$ up to $9 \mathrm{kHz}$ as a percentage of nominal current $\left(I_{n}\right)$.

Table 10. Current Distortions (2-9 kHz)

\begin{tabular}{|c|c|c|c|c|c|c|c|c|c|c|c|}
\hline $\begin{array}{l}\mathrm{P}_{\text {bin }} \\
(\%)\end{array}$ & 0 & 10 & 20 & 30 & 40 & 50 & 60 & 70 & 80 & 90 & 100 \\
\hline $\begin{array}{c}f \\
(\mathrm{kHz})\end{array}$ & $\begin{array}{c}l_{h} \\
(\%)\end{array}$ & $I_{h}(\%)$ & $\mathrm{I}_{\mathrm{h}}(\%)$ & $I_{h}(\%)$ & $\mathrm{I}_{\mathrm{h}}(\%)$ & $\mathrm{I}_{\mathrm{h}}(\%)$ & $I_{h}(\%)$ & $I_{h}(\%)$ & $\mathrm{I}_{\mathrm{h}}(\%)$ & $I_{h}(\%)$ & $I_{h}(\%)$ \\
\hline 2.1 & 0.19 & 0.19 & 0.17 & 0.17 & 0.15 & 0.14 & 0.15 & 0.15 & 0.15 & 0.16 & 0.17 \\
\hline 2.3 & 0.11 & 0.10 & 0.10 & 0.10 & 0.10 & 0.10 & 0.10 & 0.10 & 0.10 & 0.10 & 0.10 \\
\hline 2.5 & 0.06 & 0.06 & 0.07 & 0.07 & 0.07 & 0.07 & 0.07 & 0.07 & 0.07 & 0.07 & 0.07 \\
\hline 2.7 & 0.41 & 0.41 & 0.41 & 0.41 & 0.41 & 0.41 & 0.41 & 0.41 & 0.41 & 0.41 & 0.41 \\
\hline 2.9 & 0.24 & 0.25 & 0.25 & 0.26 & 0.26 & 0.26 & 0.25 & 0.26 & 0.26 & 0.25 & 0.24 \\
\hline 3.1 & 0.16 & 0.17 & 0.17 & 0.17 & 0.17 & 0.17 & 0.16 & 0.17 & 0.17 & 0.16 & 0.15 \\
\hline 3.3 & 0.04 & 0.04 & 0.04 & 0.04 & 0.04 & 0.04 & 0.04 & 0.04 & 0.04 & 0.04 & 0.04 \\
\hline 3.5 & 0.02 & 0.03 & 0.03 & 0.03 & 0.03 & 0.02 & 0.03 & 0.02 & 0.03 & 0.02 & 0.02 \\
\hline 3.7 & 0.04 & 0.05 & 0.05 & 0.06 & 0.06 & 0.06 & 0.06 & 0.07 & 0.07 & 0.07 & 0.07 \\
\hline 3.9 & 0.04 & 0.06 & 0.05 & 0.06 & 0.06 & 0.06 & 0.07 & 0.07 & 0.07 & 0.07 & 0.07 \\
\hline 4.1 & 0.02 & 0.02 & 0.02 & 0.02 & 0.02 & 0.02 & 0.02 & 0.02 & 0.02 & 0.02 & 0.02 \\
\hline 4.3 & 0.01 & 0.01 & 0.01 & 0.01 & 0.01 & 0.01 & 0.01 & 0.01 & 0.01 & 0.01 & 0.01 \\
\hline 4.5 & 0.08 & 0.09 & 0.06 & 0.07 & 0.08 & 0.07 & 0.08 & 0.07 & 0.06 & 0.08 & 0.08 \\
\hline 4.7 & 0.02 & 0.01 & 0.01 & 0.01 & 0.01 & 0.01 & 0.01 & 0.01 & 0.01 & 0.01 & 0.01 \\
\hline 4.9 & 0.01 & 0.01 & 0.01 & 0.01 & 0.01 & 0.01 & 0.01 & 0.01 & 0.01 & 0.01 & 0.01 \\
\hline 5.1 & 0.01 & 0.01 & 0.01 & 0.01 & 0.01 & 0.01 & 0.01 & 0.01 & 0.01 & 0.01 & 0.01 \\
\hline 5.3 & 0.01 & 0.01 & 0.01 & 0.01 & 0.01 & 0.01 & 0.01 & 0.01 & 0.01 & 0.01 & 0.01 \\
\hline 5.5 & 0.04 & 0.04 & 0.04 & 0.04 & 0.04 & 0.04 & 0.04 & 0.04 & 0.04 & 0.04 & 0.04 \\
\hline 5.7 & 0.05 & 0.06 & 0.05 & 0.05 & 0.05 & 0.05 & 0.05 & 0.06 & 0.05 & 0.05 & 0.05 \\
\hline 5.9 & 0.02 & 0.02 & 0.02 & 0.02 & 0.02 & 0.02 & 0.02 & 0.02 & 0.02 & 0.02 & 0.02 \\
\hline 6.1 & 0.06 & 0.06 & 0.06 & 0.06 & 0.06 & 0.06 & 0.06 & 0.06 & 0.06 & 0.06 & 0.05 \\
\hline 6.3 & 0.01 & 0.01 & 0.01 & 0.01 & 0.01 & 0.01 & 0.01 & 0.01 & 0.01 & 0.01 & 0.01 \\
\hline 6.5 & 0.01 & 0.01 & 0.01 & 0.01 & 0.01 & 0.01 & 0.01 & 0.01 & 0.01 & 0.01 & 0.01 \\
\hline 6.7 & 0.01 & 0.01 & 0.01 & 0.01 & 0.01 & 0.01 & 0.01 & 0.01 & 0.01 & 0.01 & 0.01 \\
\hline 6.9 & 0.01 & 0.01 & 0.01 & 0.01 & 0.01 & 0.01 & 0.01 & 0.01 & 0.01 & 0.01 & 0.01 \\
\hline 7.1 & 0.00 & 0.01 & 0.00 & 0.01 & 0.01 & 0.01 & 0.01 & 0.01 & 0.01 & 0.01 & 0.01 \\
\hline 7.3 & 0.00 & 0.00 & 0.00 & 0.00 & 0.01 & 0.01 & 0.01 & 0.01 & 0.01 & 0.01 & 0.01 \\
\hline 7.5 & 0.02 & 0.02 & 0.02 & 0.02 & 0.01 & 0.01 & 0.01 & 0.01 & 0.01 & 0.01 & 0.01 \\
\hline 7.7 & 0.02 & 0.02 & 0.02 & 0.02 & 0.01 & 0.01 & 0.01 & 0.01 & 0.01 & 0.01 & 0.01 \\
\hline 7.9 & 0.01 & 0.01 & 0.01 & 0.01 & 0.01 & 0.01 & 0.01 & 0.01 & 0.01 & 0.01 & 0.01 \\
\hline 8.1 & 0.01 & 0.01 & 0.01 & 0.01 & 0.01 & 0.01 & 0.01 & 0.01 & 0.01 & 0.01 & 0.01 \\
\hline 8.3 & 0.01 & 0.01 & 0.02 & 0.02 & 0.02 & 0.02 & 0.02 & 0.02 & 0.02 & 0.02 & 0.02 \\
\hline 8.5 & 0.01 & 0.01 & 0.01 & 0.01 & 0.01 & 0.01 & 0.01 & 0.01 & 0.01 & 0.01 & 0.01 \\
\hline 8.7 & 0.00 & 0.00 & 0.00 & 0.00 & 0.00 & 0.00 & 0.01 & 0.01 & 0.01 & 0.01 & 0.01 \\
\hline 8.9 & 0.01 & 0.01 & 0.01 & 0.01 & 0.01 & 0.01 & 0.01 & 0.01 & 0.01 & 0.01 & 0.01 \\
\hline
\end{tabular}


The current distortions were measured and evaluated according to Annex B of IEC $61000-4-7 / \mathrm{CDV}$ [2], as prescribed in the Standard. The window width used during measurements was $T_{w}=12$.

\subsection{Current and Voltage Imbalance}

Figure 8 and Figure 9 show the voltage and current imbalance observed during the testing. The current and voltage imbalance was calculated for each 10-minute period. The values are plotted against the average power of each 10-minute data set.

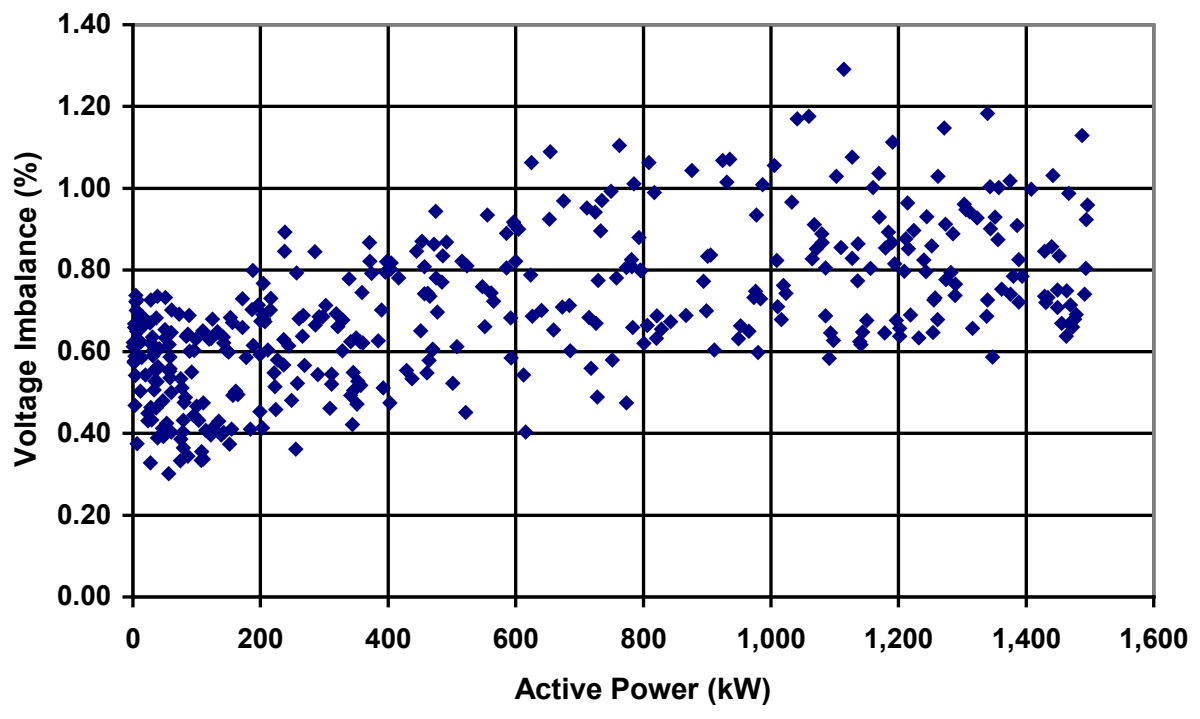

Figure 8. Voltage imbalance versus active power 


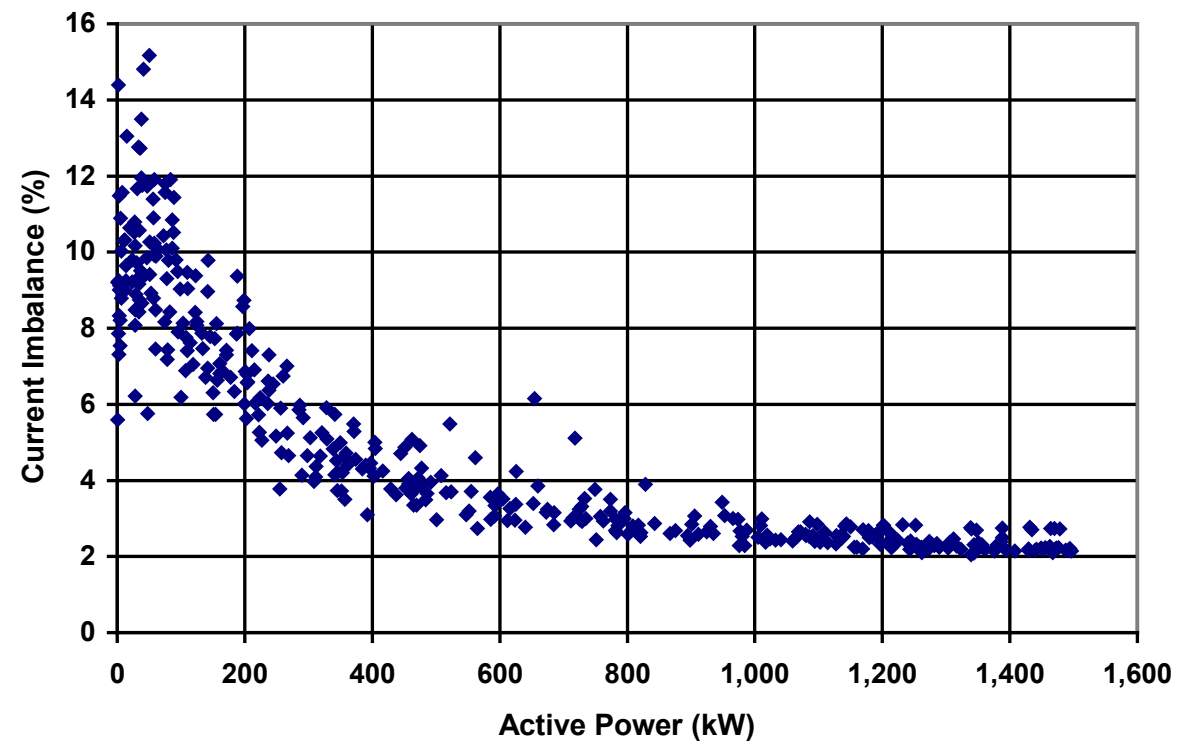

Figure 9. Current imbalance versus active power

\subsection{Continuous Operation Flicker}

The flicker coefficients $c\left(\Psi_{k}, V_{a}\right)$ were determined according to procedures listed in the Standard. A total of 730 10-minute interval data bins were collected for this test.

Figure 10 through Figure -13 show graphs of fictitious grid flicker coefficients as a function of 10-minute average active power for four different impedance phase angles $\left(30^{\circ}, 50^{\circ}, 70^{\circ}\right.$, and $\left.85^{\circ}\right)$. Resulting flicker coefficients for continuous operation are shown in Table 11. The ratio between three-phase short circuit apparent power of the fictitious grid $S_{k, f i c}$ and turbine rated apparent power $S_{n}$ used for the analysis was 50 .

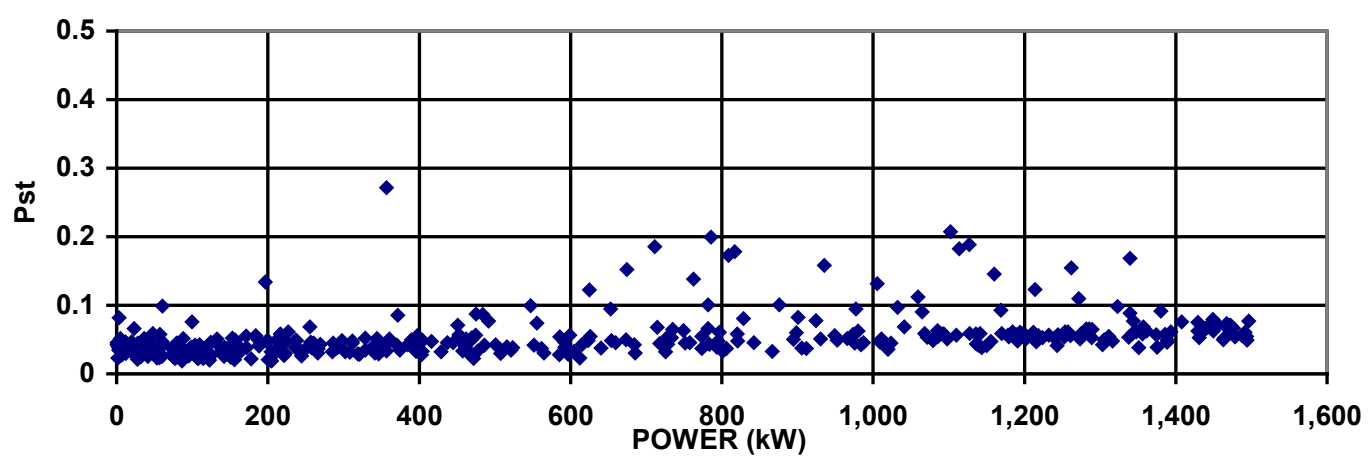

Figure 10. Short-term flicker $\left(P_{s t}\right)$ versus power for $30^{\circ}$ network impedance angle 


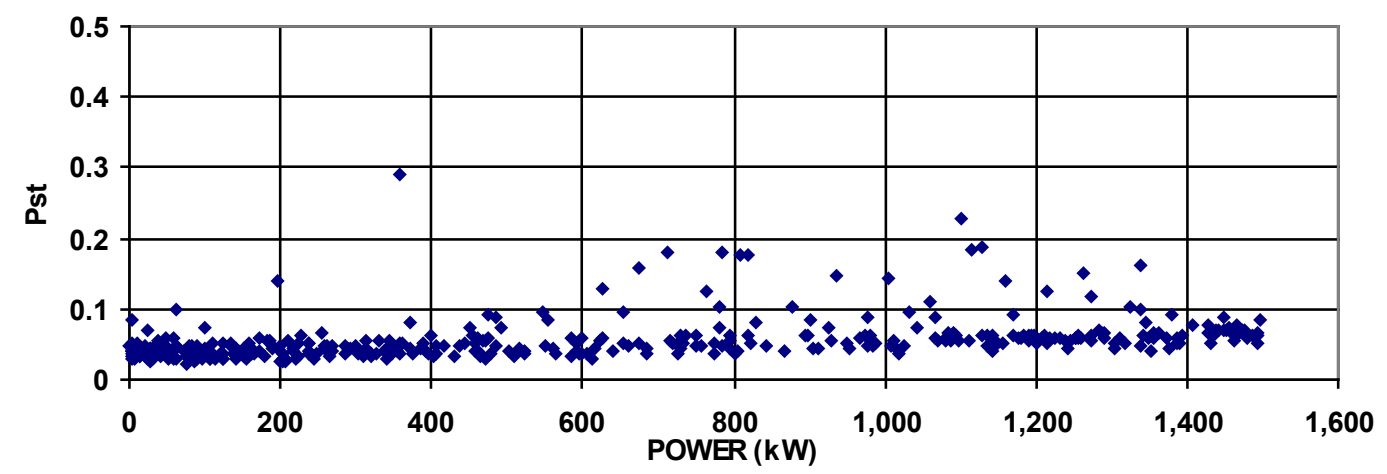

Figure 11. Short-term flicker $\left(P_{s t}\right)$ versus power for $50^{\circ}$ network impedance angle

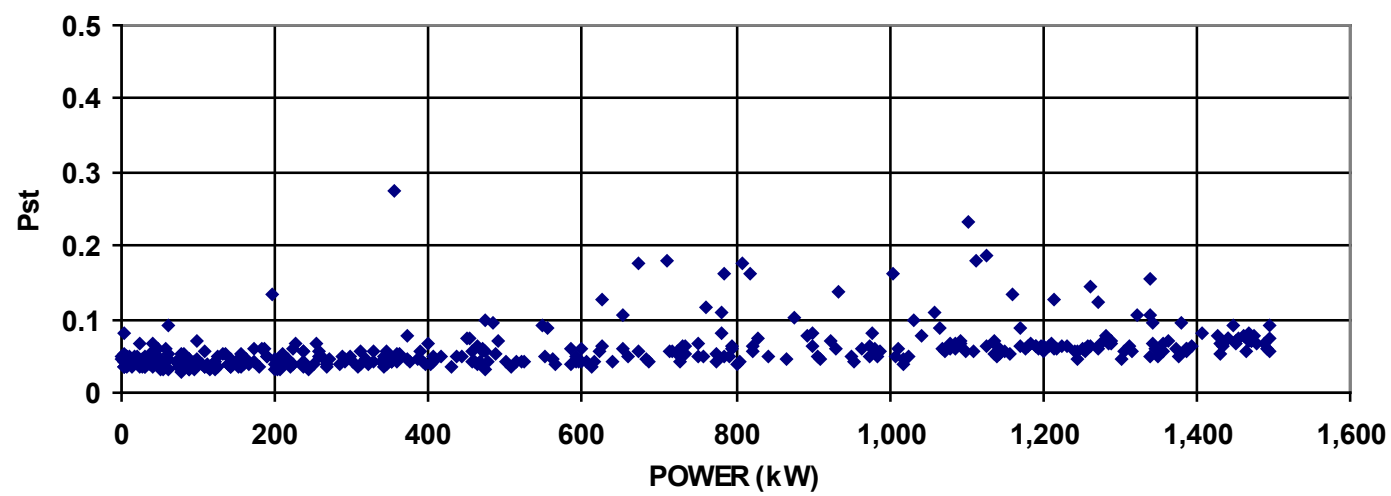

Figure 12. Short-term flicker $\left(P_{s t}\right)$ versus power for $70^{\circ}$ network impedance angle

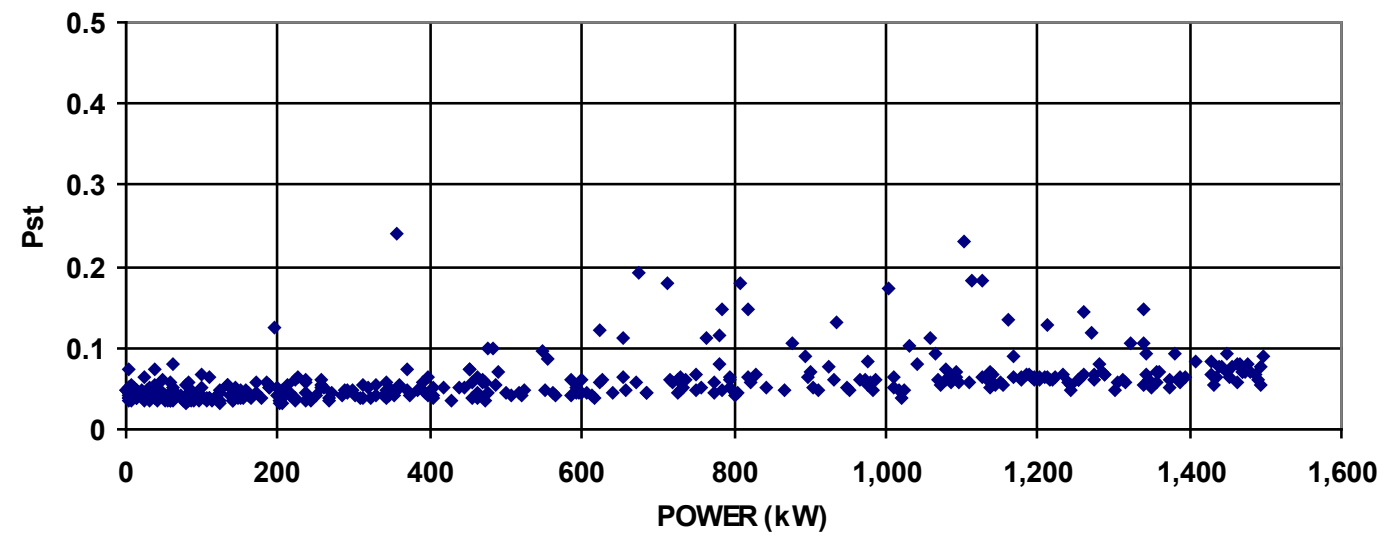

Figure 13. Short-term flicker $\left(P_{s t}\right)$ versus power for $85^{\circ}$ network impedance angle

The simulated flicker values $P_{s t}$ depend on short-circuit apparent power of the fictitious grid $\left(S_{k, f i c}\right)$ and the grid impedance angle. To reduce this dependency, the Standard defines a flicker coefficient $c\left(\Psi_{k}, V_{a}\right)$, which is calculated as a normalized quantity according to the Standard, where $\Psi_{k}$ is the network impedance phase angle and $V_{a}$ is the 
annual average wind speed. Table 11 shows the flicker coefficient of the wind turbine for the actual $\Psi_{k}$ and $V_{a}$ at the site, as calculated by applying linear interpolation.

Table 11. Resulting Flicker Coefficients $c\left(\Psi_{k}, V_{a}\right)$ in Continuous Operation

\begin{tabular}{|c|c|c|c|c|c|}
\hline Network impedance phase angle, $\Psi_{\boldsymbol{k}}(\mathrm{deg}):$ & $30^{\circ}$ & $\mathbf{5 0}$ & $\mathbf{7 0 ^ { \circ }}$ & $\mathbf{8 5 ^ { \circ }}$ \\
\hline Annual average wind speed, $\boldsymbol{V}_{\mathbf{a}}(\mathbf{m} / \mathbf{s}):$ & \multicolumn{4}{|l|}{ Flicker coefficients, $c\left(\Psi_{k}, V_{a}\right):$} \\
\hline $\mathbf{6}$ & 7.43 & 7.57 & 7.78 & 7.45 \\
\hline $\mathbf{7 . 5}$ & 7.43 & 7.57 & 7.78 & 7.45 \\
\hline $\mathbf{8 . 5}$ & 7.43 & 7.57 & 7.78 & 7.45 \\
\hline $\mathbf{1 0}$ & 7.43 & 7.57 & 7.78 & 7.45 \\
\hline
\end{tabular}




\section{Switching Operation Test Results}

\subsection{Turbine Starts and Stops}

Normal start and stop tests were conducted at cut-in and rated wind speeds. The hubheight meteorological tower wind speed was recorded during the tests along with voltage and current waveforms. The resulting 10-minute average wind speed during the switching operation was within $\pm 2 \mathrm{~m} / \mathrm{s}$ of the required test wind speed. The measurements were taken for a long enough period to ensure that the transient of the switching operation had abated but not so long as to introduce possible power fluctuations due to turbulence. The switching operation measurements ranged from 30 seconds to 2 minutes.

Figure 14 through Figure 21 show the transients for the start and stop cases for active power, reactive power, and current. The time series RMS voltages for Phase A are also shown for each case to illustrate voltage fluctuations during switching operations.

The voltage and current time series were combined as prescribed by the Standard to simulate a fictitious voltage time series $u_{f i c}(t)$ for four different network impedance angles. The flicker step factors and voltage change factors were determined for each switching operation for four impedance angles (Table 12 through-Table 15).

Cut-in start waveforms are shown in Figure 14 and Figure 15. Rated start waveforms are shown in Figure 16 and Figure 17.
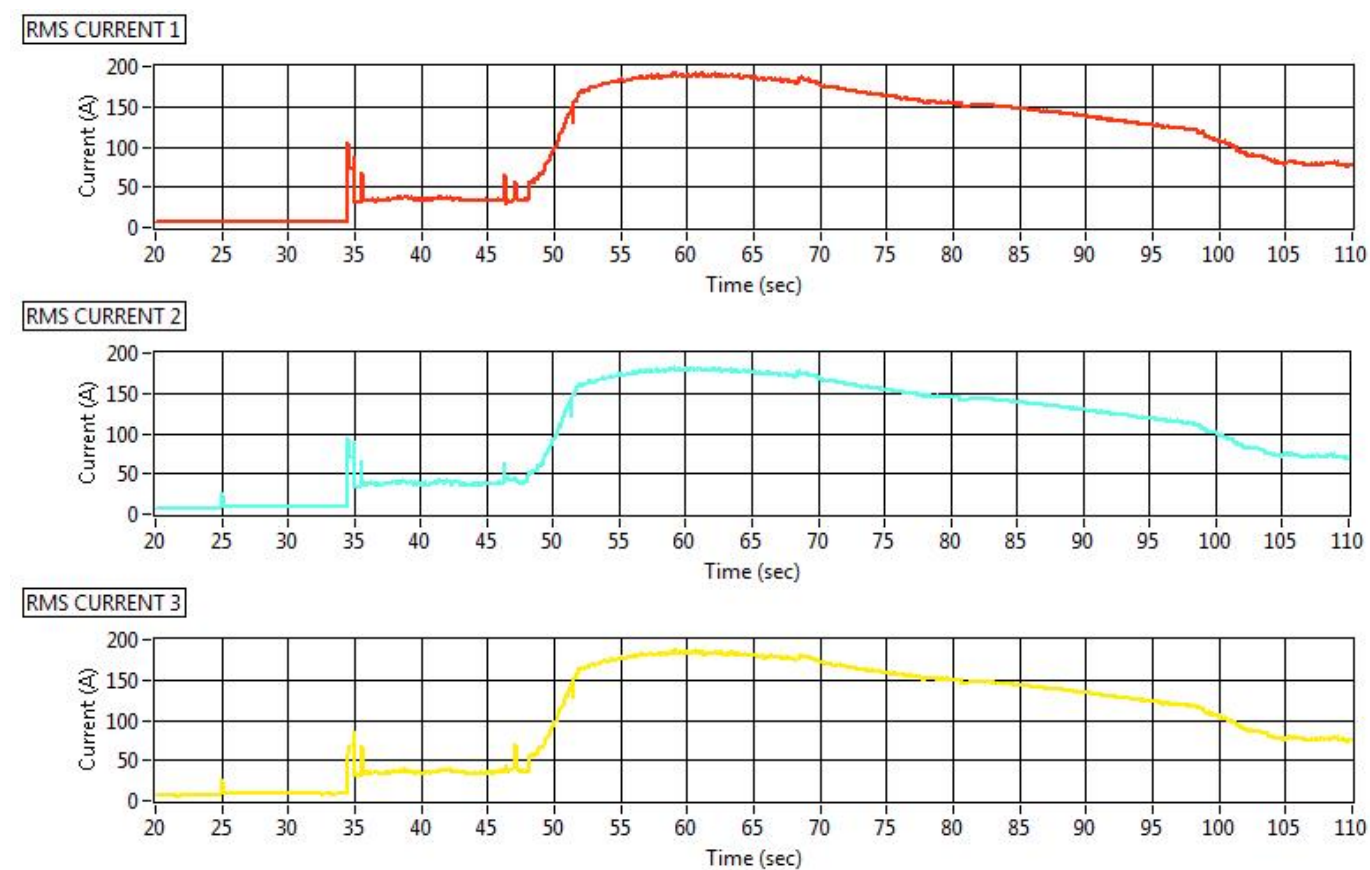

Figure 14. Cut-in wind $(5.3 \mathrm{~m} / \mathrm{s})$ start: current (May 18, 2011) 

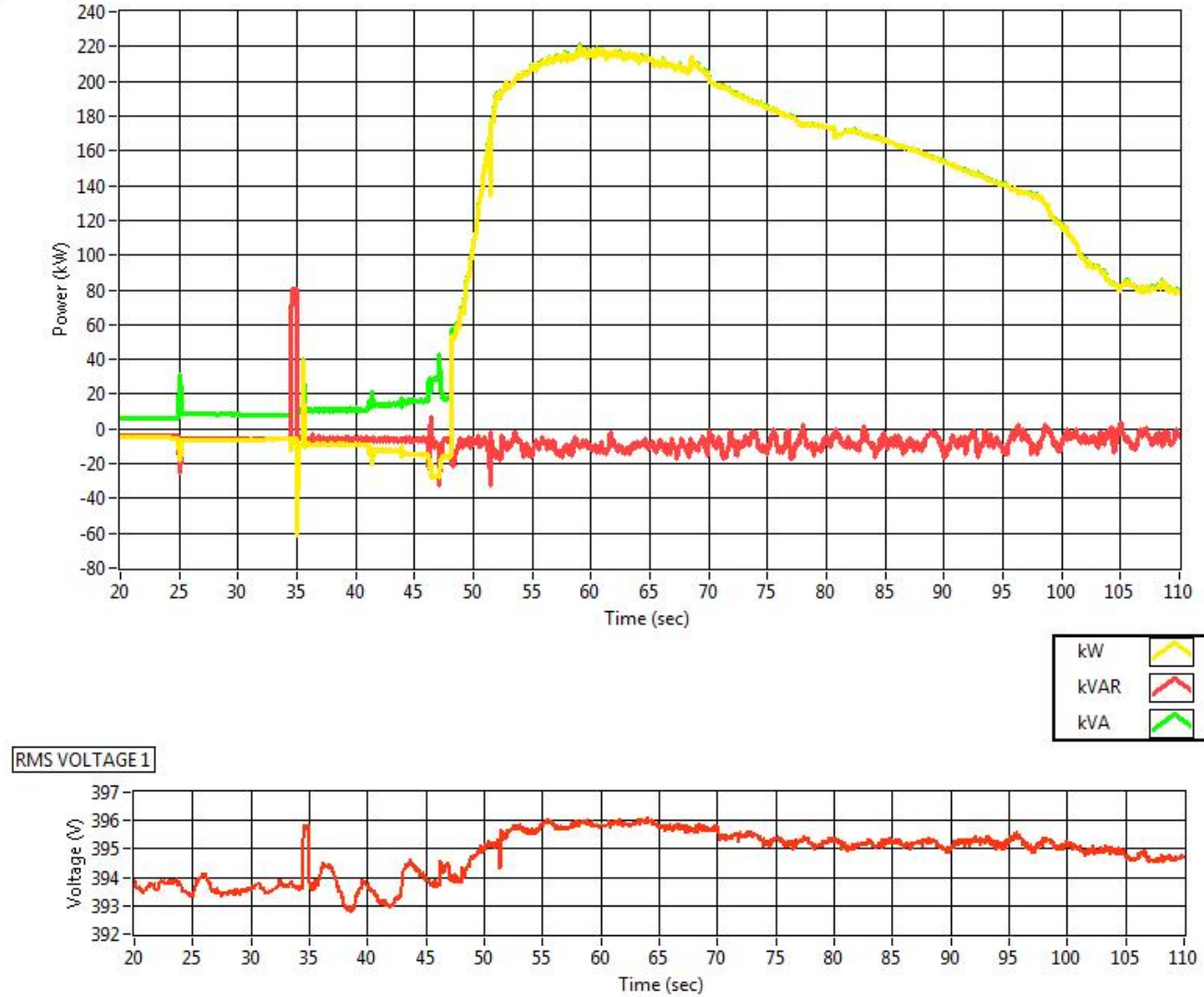

Figure 15. Cut-in wind $(5.3 \mathrm{~m} / \mathrm{s})$ start: power and RMS voltage (May 18, 2011)

\section{RMS CURRENT 1}

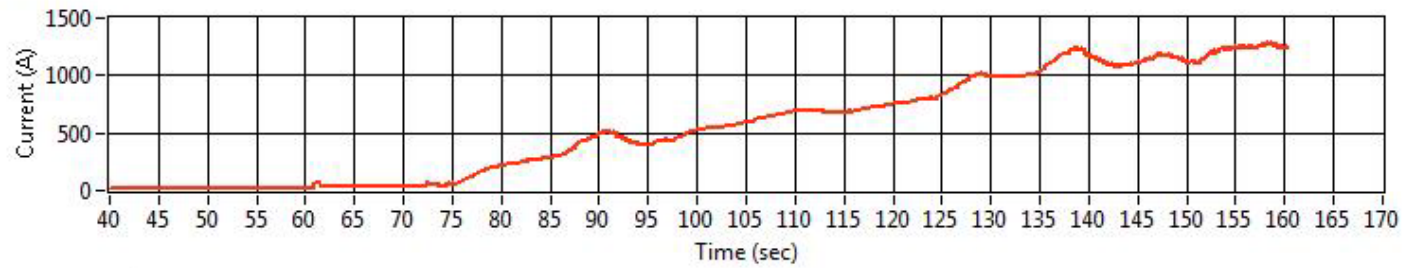

RMS CURRENT 2

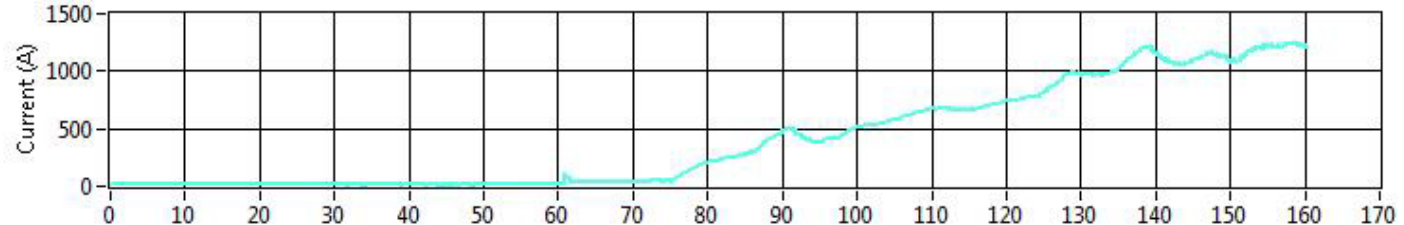

RMS CURRENT 3

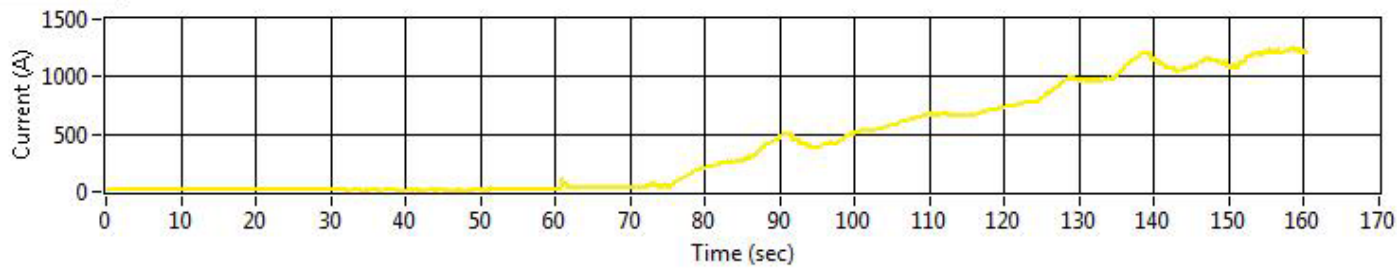

Figure 16. Rated wind $(13.1 \mathrm{~m} / \mathrm{s})$ start: current (April 19, 2011) 

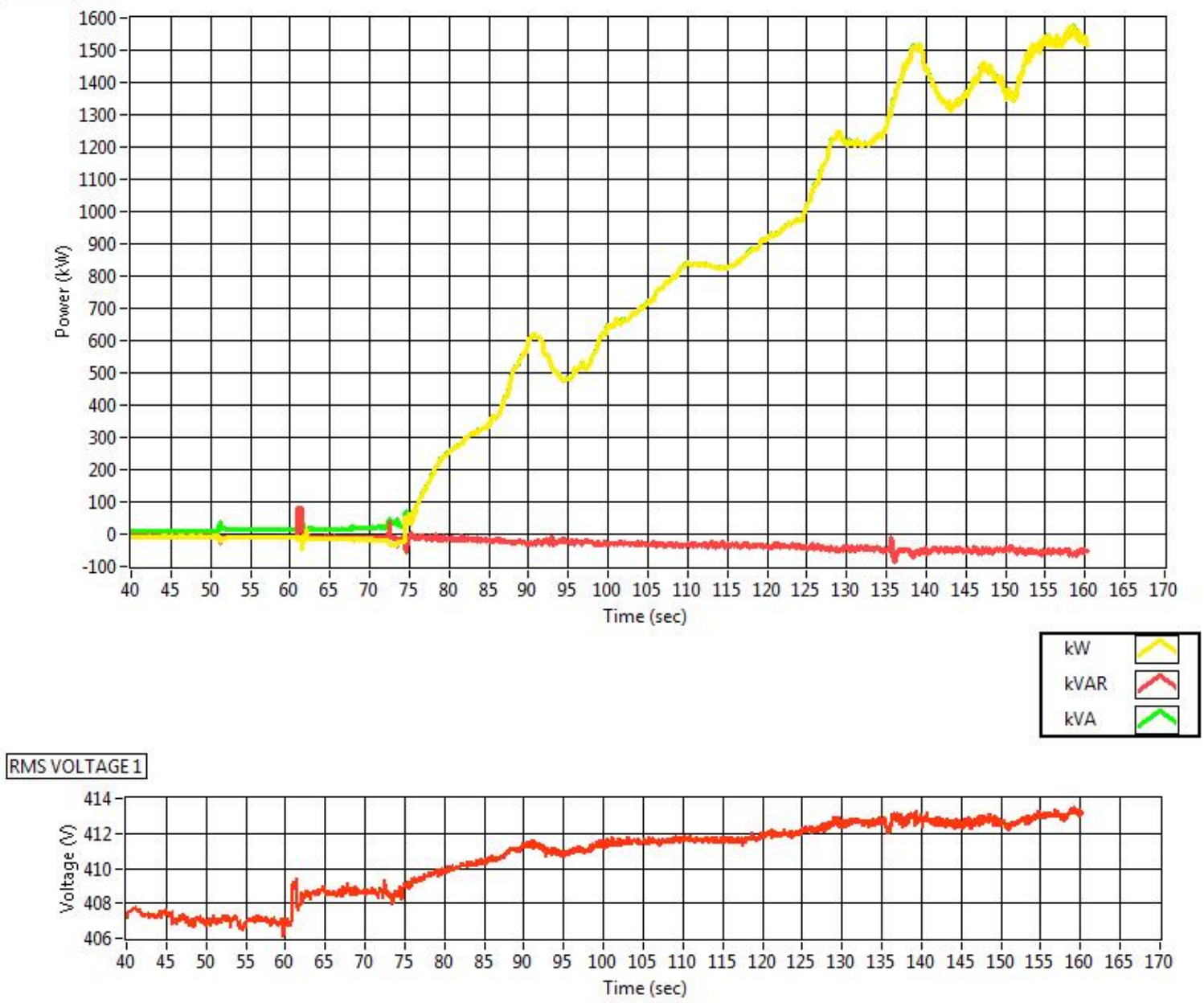

Figure 17. Rated wind $(13.1 \mathrm{~m} / \mathrm{s})$ start: power and RMS voltage (April 19, 2011)

Cut-in stop waveforms are shown in Figure 18 and Figure 19. Rated stop waveforms are shown in Figure 20 and Figure 21. 
RMS CURRENT 1

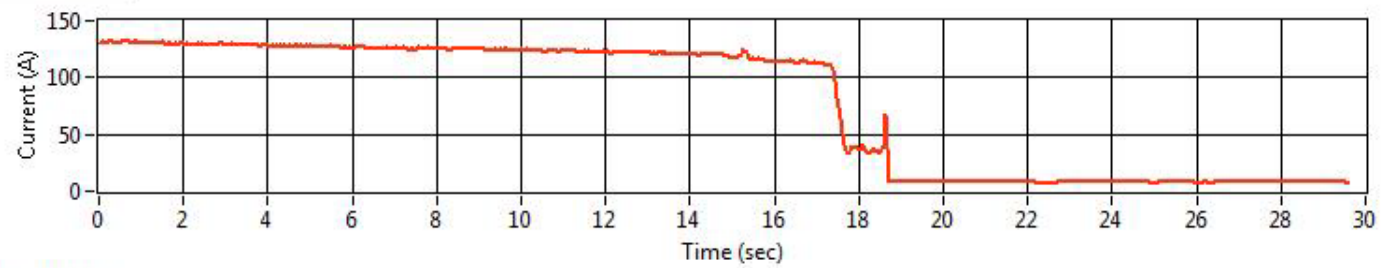

RMS CURRENT 2

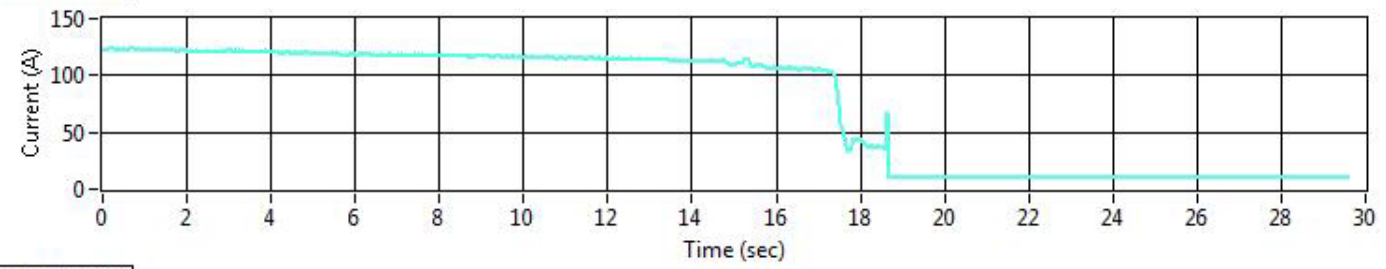

RMS CURRENT 3

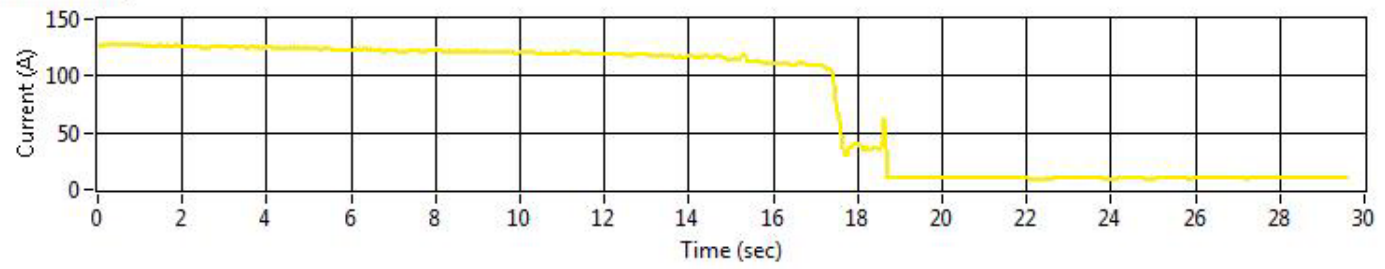

Figure 18. Cut-in wind $(5.0 \mathrm{~m} / \mathrm{s})$ stop: current (May 18, 2011) 

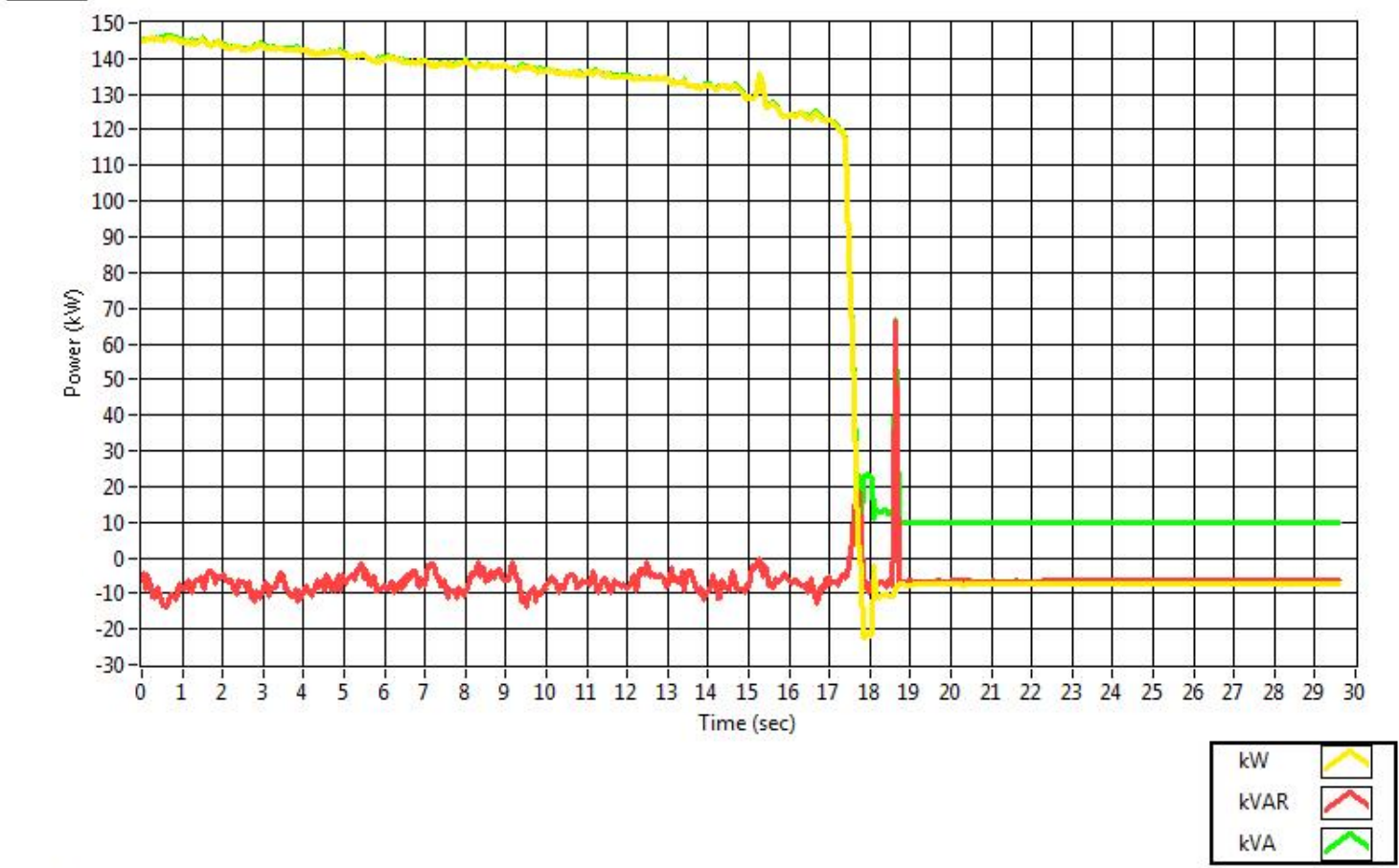

RMS VOLTAGE 1.

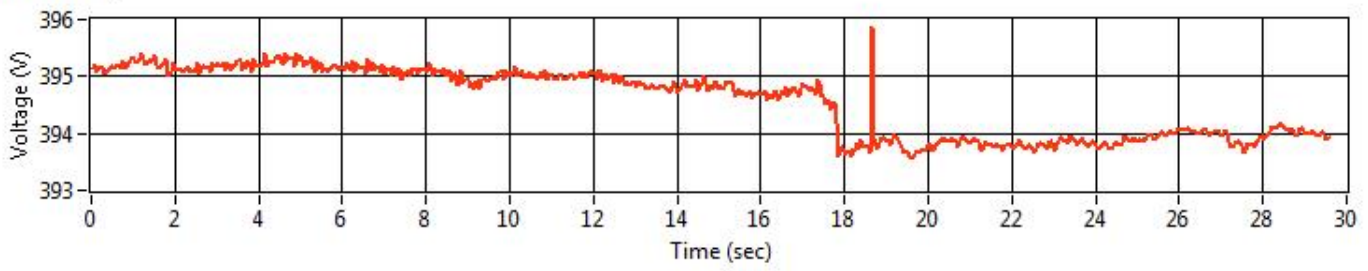

Figure 19. Cut-in wind $(5.0 \mathrm{~m} / \mathrm{s})$ stop: power and RMS voltage (May 18, 2011) 
RMS CURRENT 1

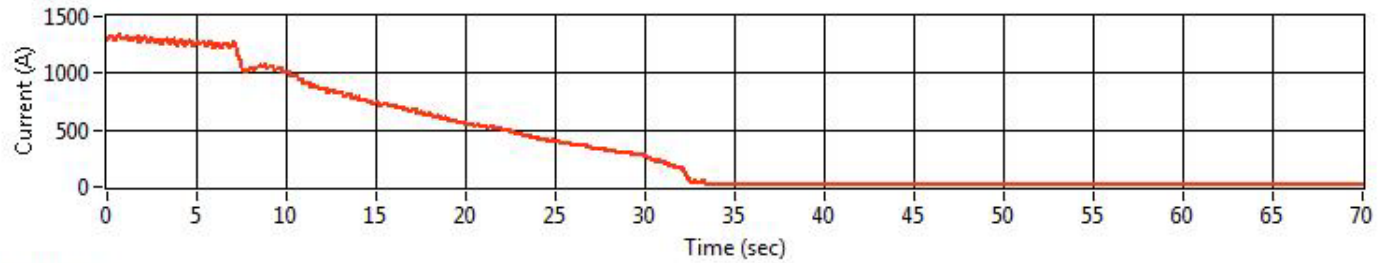

RMS CURRENT 2

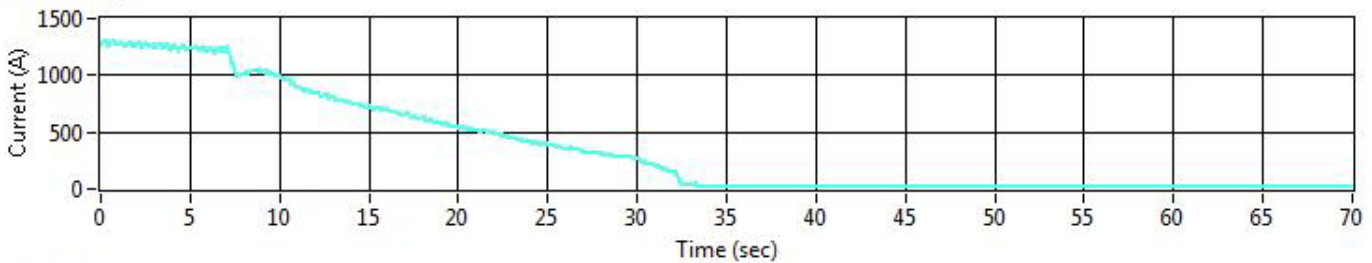

RMS CURRENT 3

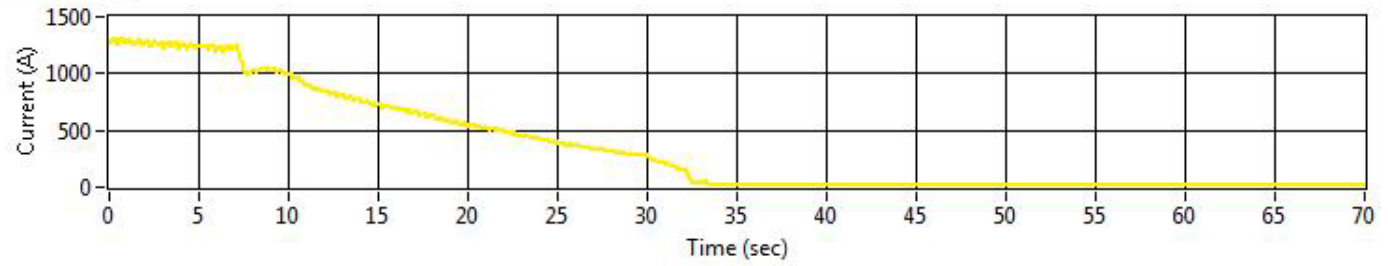

Figure 20. Rated wind (13.8 m/s) stop: current (April 19, 2011) 

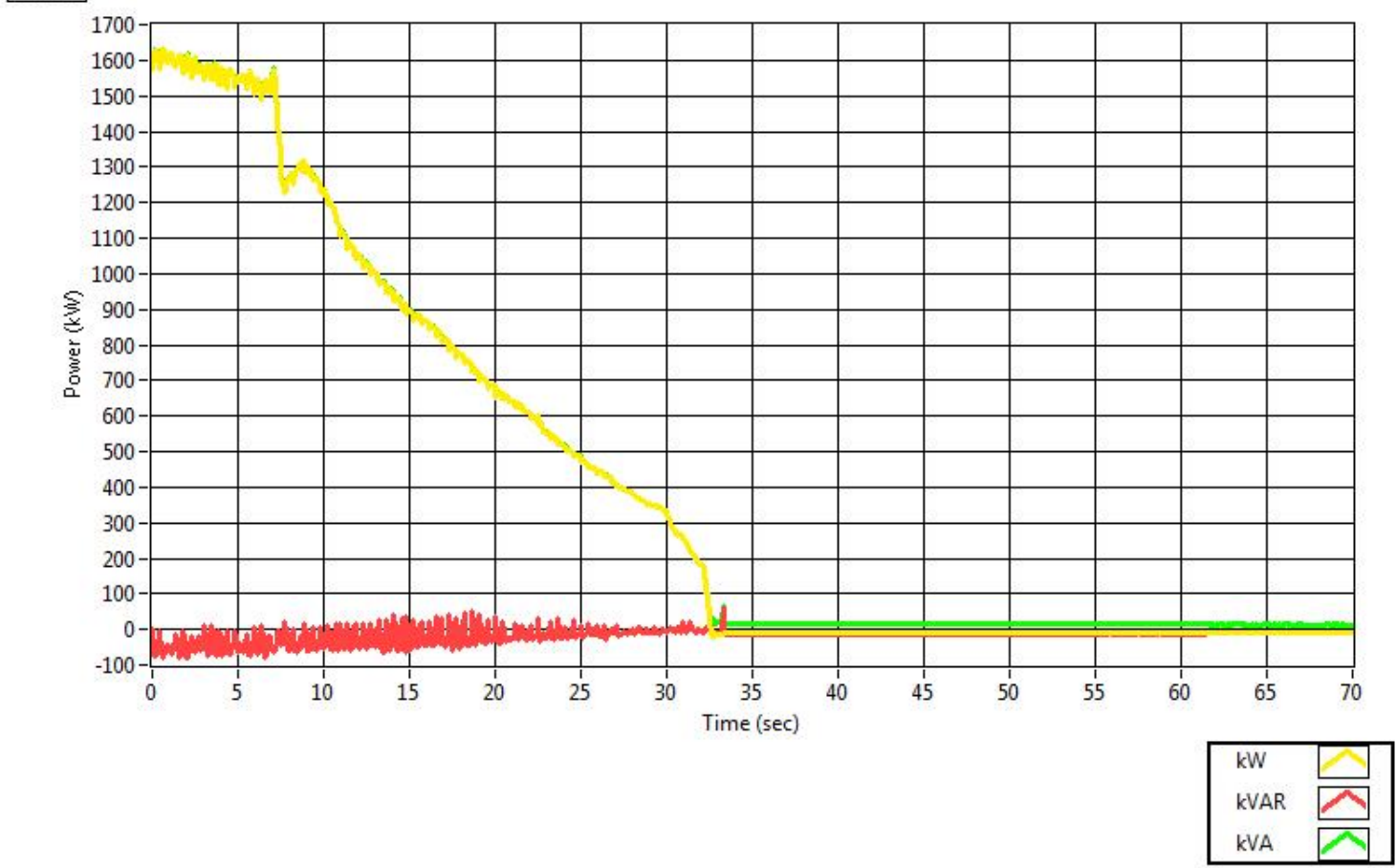

RMS VOLTAGE 1

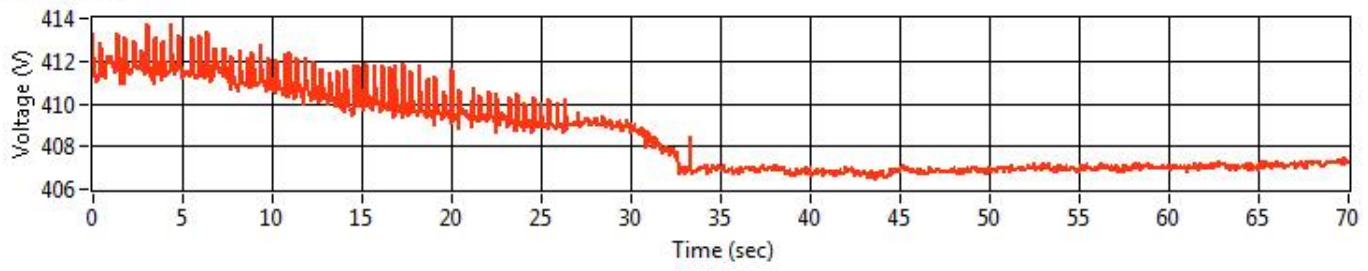

Figure 21. Rated wind (13.8 m/s) stop: power and RMS voltage (April 19, 2011)

The maximum number of switching operations for 10-minute and 120-minute intervals $\left(N_{10 m}\right.$ and $\left.N_{120 m}\right)$ was 10 and 120 for cut-in and 1 and 1 for rated wind speeds, respectively. The $N_{10}$ and $N_{120}$ values were assumed based on the procedure defined by the Standard. The flicker step factor and voltage change factors were the averaged result of five starts and stops at cut-in and rated wind speeds. These values are shown in Table 12 through Table15.

Table 12. Characteristics of a Start at Cut-In Wind Speed

\begin{tabular}{|l|c|c|c|c|}
\hline Case of switching operation & \multicolumn{4}{|c|}{ Start at cut-in wind speed } \\
\hline Maximum number of switching operations, $N_{10 m}$ & \multicolumn{4}{|c|}{10} \\
\hline Maximum number of switching operations, $N_{120 m}$ & $30^{\circ}$ & $50^{\circ}$ & $70^{\circ}$ & $85^{\circ}$ \\
\hline Network impedance angle, $\Psi_{k}$ & 0.015 & 0.015 & 0.015 & 0.015 \\
\hline Flicker step factor, $k_{f}\left(\Psi_{k}\right)$ & 0.028 & 0.036 & 0.042 & 0.043 \\
\hline Voltage change factor, $k_{U}\left(\Psi_{k}\right)$ & &
\end{tabular}


Table 13. Characteristics of a Stop at Cut-In Wind Speed

\begin{tabular}{|l|c|c|c|c|}
\hline Case of switching operation & \multicolumn{4}{|c|}{ Stop at cut-in wind speed } \\
\hline Maximum number of switching operations, $N_{10: m}$ & \multicolumn{5}{|c|}{10} \\
\hline Maximum number of switching operations, $N_{120 m}$ & $30^{\circ}$ & $50^{\circ}$ & $70^{\circ}$ & $85^{\circ}$ \\
\hline Network impedance angle, $\Psi_{k:}$ & 0.095 & 0.116 & 0.132 & 0.140 \\
\hline Flicker step factor, $k_{f}\left(\Psi_{k}\right):$ & 0.017 & 0.017 & 0.017 & 0.017 \\
\hline Voltage change factor, $k_{U}\left(\Psi_{k}\right):$ &
\end{tabular}

Table 14. Characteristics of a Start at Rated Wind Speed

\begin{tabular}{|l|c|c|c|c|}
\hline Case of switching operation: & \multicolumn{4}{|c|}{ Start at rated wind speed } \\
\hline Maximum number of switching operations, $N_{10 m:}$ & \multicolumn{5}{|c|}{12} \\
\hline Maximum number of switching operations, $N_{120 m:}$ & $30^{\circ}$ & 50 & $70^{\circ}$ & $85^{\circ}$ \\
\hline Network impedance angle, $\Psi_{k:}$ & 0.000 & 0.000 & 0.000 & 0.000 \\
\hline Flicker step factor, $k_{f}\left(\Psi_{k}\right):$ & 0.030 & 0.039 & 0.046 & 0.048 \\
\hline Voltage change factor, $k_{U}\left(\Psi_{k}\right):$ & &
\end{tabular}

Table 15. Characteristics of a Stop at Rated Wind Speed

\begin{tabular}{|c|c|c|c|c|}
\hline Case of switching operation: & \multicolumn{4}{|c|}{ Stop at rated wind speed } \\
\hline Maximum number of switching operations, $N_{10 m:}$ & \multicolumn{4}{|c|}{1} \\
\hline Maximum number of switching operations, $N_{120 m:}$ & \multicolumn{4}{|c|}{12} \\
\hline Network impedance angle, $\Psi_{k:}$ & $30^{\circ}$ & $50^{\circ}$ & $70^{\circ}$ & $85^{\circ}$ \\
\hline Flicker step factor, $k_{f}\left(\Psi_{k}\right)$ : & 0.000 & 0.000 & 0.000 & 0.000 \\
\hline Voltage change factor, $k_{U}\left(\Psi_{k}\right)$ : & 0.011 & 0.011 & 0.011 & 0.011 \\
\hline
\end{tabular}

The flicker step factor and voltage change factor of the wind turbine for the actual $\Psi_{k}$ at the site can be found from the tables above by applying linear interpolation. 


\section{Uncertainty}

The data acquisition system (DAS) consists of:

- National Instrument's cDAQ-9172

- Two NI 9239 24-bit modules with four analog inputs

- Serial numbers:14D84D5, 14D84FE

- Three LEM CV3-1200 voltage transformers

○ Serial numbers: 947323,947325, 947322

- Three LEMflex RR3035 current transformers

○ Serial numbers: F06110402818, F06110403118, F05461044218

- One Thies Clima 4.3351.10.0000

○ Serial Number: 0909219

- LabVIEW software developed by NREL, Version 6.10

- Max sampling rate $25 \mathrm{kHz}$ for continuous operation

- Max sampling rate $5 \mathrm{kHz}$ for transients

The uncertainty of the measuring system is given in Table 16.

Table 16. Uncertainty Analysis of the Measuring System

\begin{tabular}{|c|c|c|c|}
\hline Measured Value & Gain Error & Offset Error & $\begin{array}{l}\text { Overall Uncertainty of the } \\
\text { Measured Value }\end{array}$ \\
\hline Active and reactive power & $\begin{array}{c}\mathrm{A} / \mathrm{D} 0.13 \% \\
\text { Current } \\
\text { transformer } \\
1.0 \% \\
\text { Voltage } \\
\text { transformer } \\
0.2 \%\end{array}$ & A/D $0.06 \%$ & $\begin{array}{l}\text { Active power: } 1.6 \% \\
\text { Reactive power: } 1.6 \%\end{array}$ \\
\hline $\begin{array}{c}\text { Harmonic current } \\
\text { (Sampling rate } 25 \mathrm{kHz} \text { ) }\end{array}$ & $\begin{array}{c}\text { Harmonics up } \\
\text { to } 9 \mathrm{kHz} \\
\text { Bandwidth } 5 \mathrm{~Hz} \\
1.4 \% \text { of } \\
\text { measured value }\end{array}$ & $\begin{array}{c}\text { Harmonics up } \\
\text { to } 9 \mathrm{kHz} \\
\text { Bandwidth } 5 \\
\mathrm{~Hz} \\
0.06 \% \text { of } \\
\text { rated current }\end{array}$ & $\begin{array}{c}0.06 \% \text { of rated current }+1.4 \% \\
\text { of measured value }\end{array}$ \\
\hline
\end{tabular}




\section{Exceptions}

\subsection{Exceptions to the Standard}

There were two identified exceptions to the Standard. The response to temporary voltage drop test and the grid protection test that are required by the second edition were not performed because the necessary test assets were not available in North America.

Also, because the necessary technical information was confidential and not available from the manufacturer, the following tests were excluded from this testing campaign:

- Power control

- Voltage drop response

- Grid connection and reconnection.

\subsection{Exceptions to the Test Plan}

There were no deviations from the test plan [4]. 


\section{References}

1. International Electrotechnical Commission (IEC). (2008). "Wind Turbines, Part 21: Measurement and Assessment of Power Quality Characteristics of Grid Connected Wind Turbines." IEC 61400-21. Edition 2.0, 2008-08. Geneva, Switzerland.

2. IEC. (2002). "IEC 61000-4-7 Testing and Measurement Techniques - General Guide on Harmonics and Interharmonics Measurements and Instrumentation, for Power Supply Systems and Equipment Connected Thereto." Geneva, Switzerland.

3. Institute of Electrical and Electronics Engineers. (1993). "IEEE 519-1992: IEEE Recommended Practices and Requirements for Harmonic Control in Electrical Power Systems.” New York, New York.

4. QF02 Power Quality Test Plan DOE 1.5101006 


\section{Appendix A. Calibration Reports}

\section{Power}

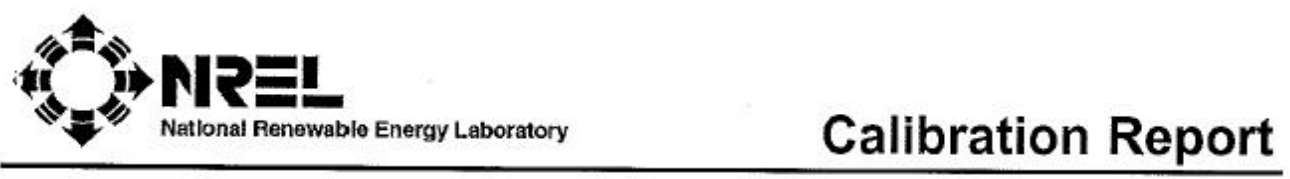

Report \#: $\quad$ NREL PQ Sampling System Cal (sn PQ05) 100813

Calibration of: NREL PQ Sampling System

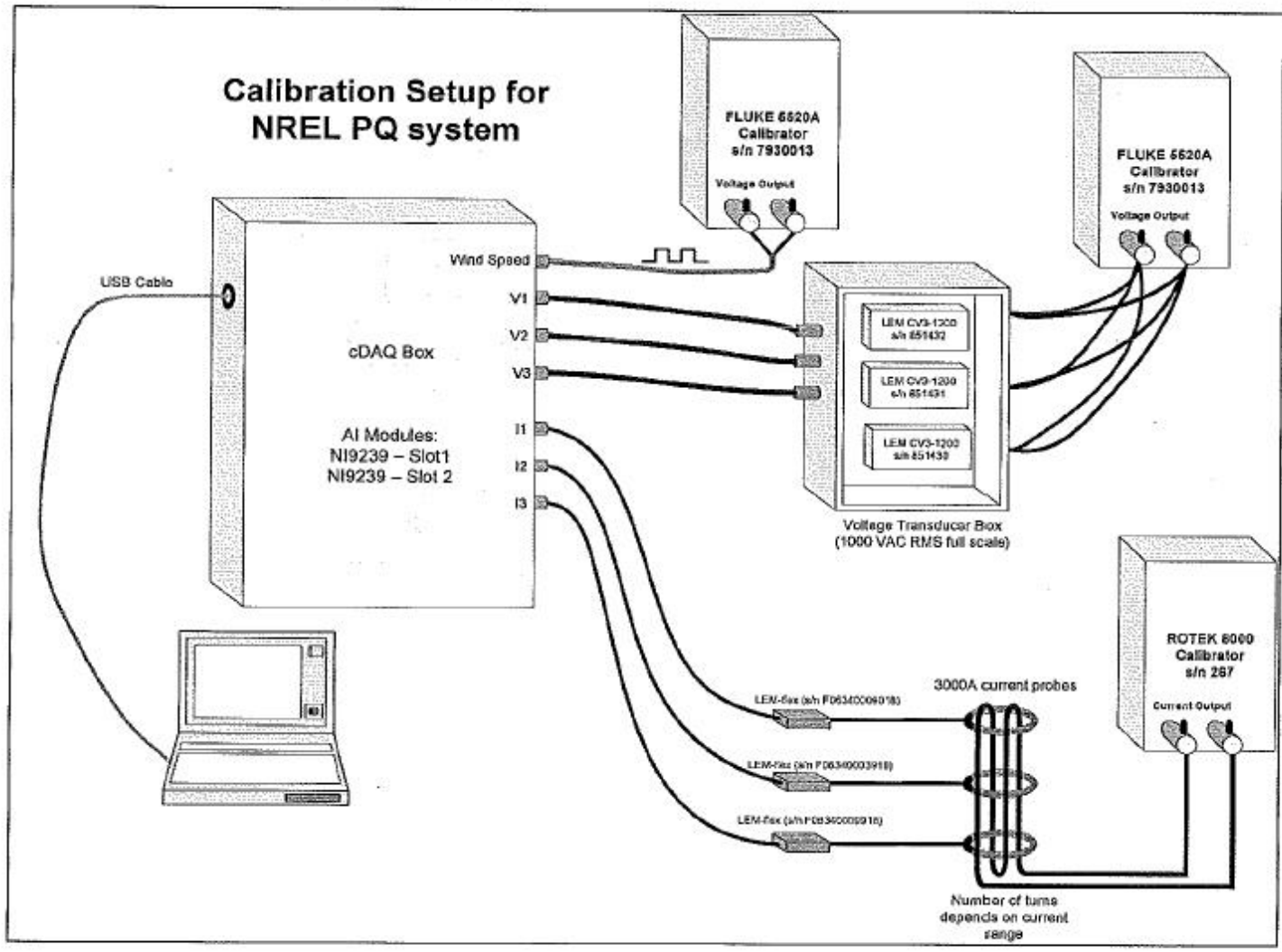

\section{Calibration Method: $\quad$ GI28 010717 \\ Calibration Results: Within tolerance \\ Device Condition: good \\ Date Calibrated: \\ $8 / 12 / 2010$ \\ Calibration Due Date: 8/12/2011 \\ Calibrated by: Amy, Ismael, and Reda}

Environmental Conditions During Calibratlon

NREL Metrology Laboratory: Ibrahim Reda

Senior Scientist-ll

Date: $8 / 17 / 2010$

8/17/2010 PQ Sampling System Cal Report (sn PQ05) 10041320100812 (version 1).xlsx

Page 1 of 6

Figure A-1. Calibration sheet for the power transducer (page 1) 
Calibration Standard: Rotek Current Calibrator

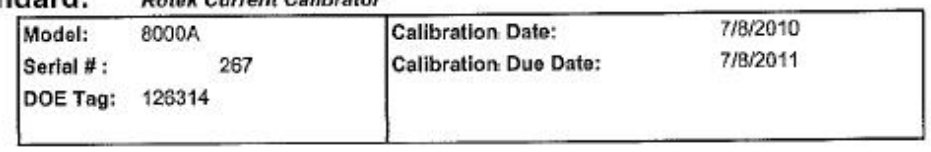

Fluke Voltage Calibrafor
\begin{tabular}{|ll|ll|}
\hline Model: & $5520 \mathrm{~A}$ & Calibration Date: & $7 / 29 / 2010$ \\
Serial \# : & 7930013 & Callbration Due Date: & $7 / 29 / 2011$ \\
DOE Tag: & 126410 & & \\
\hline
\end{tabular}

Accuracy
\begin{tabular}{rrc|}
\hline Current (<50A): & $0.036 \%$ of setting + & $0.005 \%$ of range \\
Current (>50A): & $0.05 \%$ of reading + & $0.008 \%$ of range \\
Voltage: & $0.03 \%$ of reading + & $0.01 \mathrm{~V}$ \\
\hline
\end{tabular}

Full Scale Settings
\begin{tabular}{|ll|}
\hline Rotek 8000A Current: & $200 \mathrm{~A}$ \\
Fluke 5520A Voltage: & $700 \mathrm{~V}$ \\
\hline
\end{tabular}

Unit Under Test (UUT):

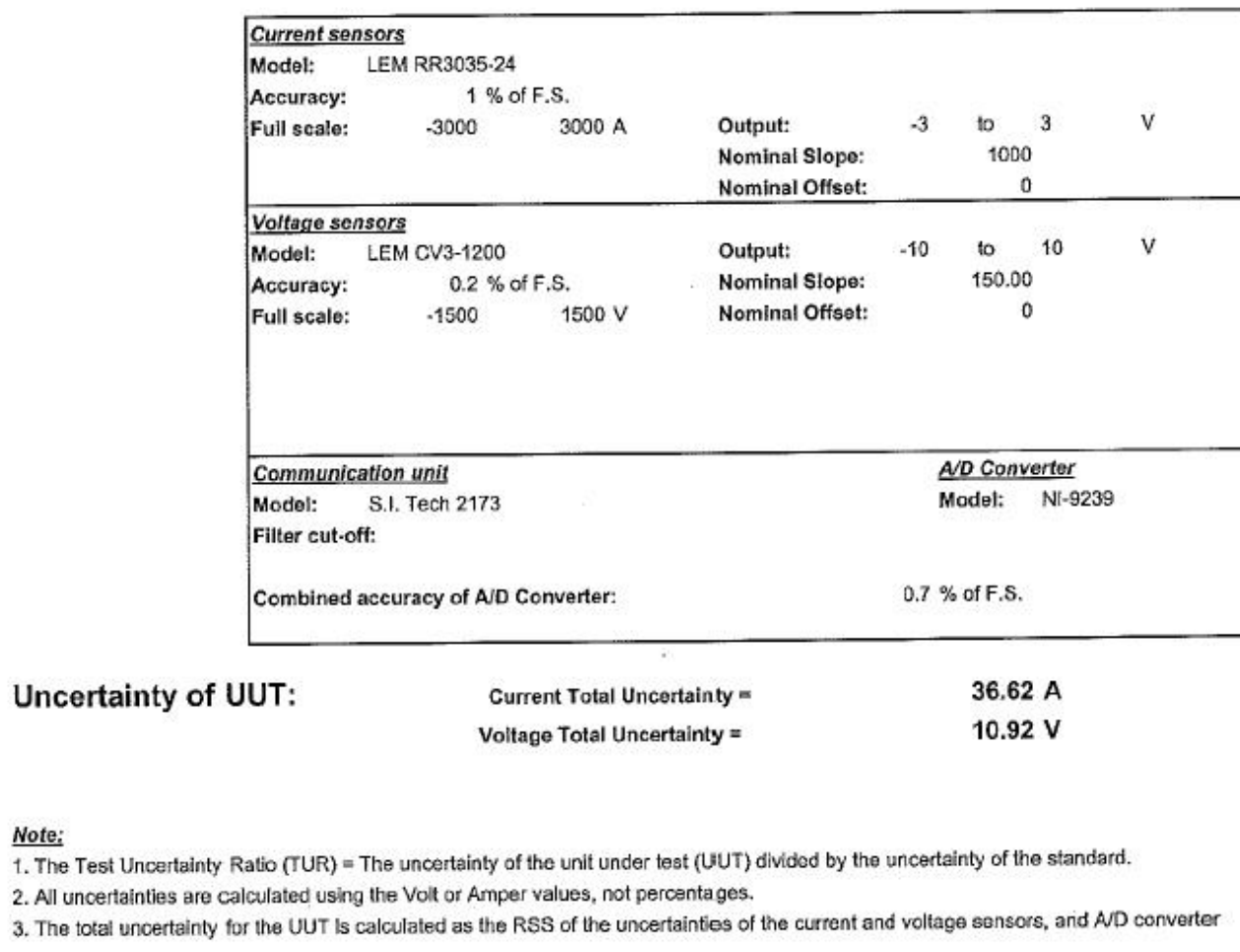

$8 / 17 / 2010$ PQ Sampling System Cal Report (sn PQ05) 100413 20100812 (version 1).xisx

Page 2 of 6

Figure A-2. Calibration sheet for the power transducer (page 2) 


\section{Current Measurements}

\begin{tabular}{|c|c|c|c|c|c|c|c|c|}
\hline ROTEK $8000 \mathrm{~A}$ & \multirow{3}{*}{$\begin{array}{c}\text { Within } \\
\text { Tolerance? }\end{array}$} & \multicolumn{6}{|c|}{ Unit Under Test } & \multirow{3}{*}{ TUR } \\
\hline RMS Current & & \multicolumn{2}{|l|}{ Phase 1} & \multicolumn{2}{|c|}{ Phase 2} & \multicolumn{2}{|l|}{ Phase 3} & \\
\hline A & & V & Error, A & V & Error, A & V & Error, A & \\
\hline 0 & Yes & 0.001 & -2.08 & 0.001 & 2.72 & 0.001 & 2.64 & 3662 \\
\hline 200 & Yes & 0.203 & -0.19 & 0.203 & 0.11 & 0.202 & -0.01 & 447 \\
\hline 400 & Yes & 0.405 & 1.69 & 0.406 & -1.52 & 0.404 & -1.68 & 238 \\
\hline 600 & Yes & 0.608 & 4.58 & 0.608 & -4.12 & 0,606 & -3.35 & 162 \\
\hline 800 & Yes & 0.802 & -1.52 & 0.818 & 1.09 & 0.814 & 0.87 & 123 \\
\hline 1000 & Yes & 1.002 & -1.64 & 1.022 & 0.44 & 1.017 & 0.18 & 99 \\
\hline 1200 & Yes & 1.203 & -0.75 & 1.227 & 0.77 & 1.221 & 0.47 & 83 \\
\hline 1400 & Yes & 1.403 & -0.86 & 1.431 & 0.12 & 1.425 & 0.77 & 71 \\
\hline 1600 & Yes & 1.604 & 0.03 & 1.636 & 0.45 & 1.628 & 0.08 & 62 \\
\hline 1800 & Yes & 1.804 & -0.08 & 1.840 & -0.20 & 1.832 & 0.37 & 56 \\
\hline 2000 & Yes & 2.005 & 0.81 & 2.045 & 0.13 & 2.035 & -0.32 & 50 \\
\hline \multicolumn{8}{|c|}{ Calculated slope and offset: } & \multirow[t]{3}{*}{ TUR is al } \\
\hline & Slope: & \multicolumn{2}{|l|}{999.45} & \multicolumn{2}{|l|}{977.21} & \multicolumn{2}{|l|}{981.83} & \\
\hline & Offset: & \multicolumn{2}{|l|}{-3.0811999} & \multicolumn{2}{|l|}{1.7388932} & \multicolumn{2}{|l|}{1.656462} & \\
\hline
\end{tabular}

Frequency Measurements

\begin{tabular}{|c|c|c|c|}
\hline Fluke $5520 \mathrm{~A}$ & \multirow{3}{*}{$\begin{array}{c}\text { Wilhin } \\
\text { Tolerance? }\end{array}$} & \multirow{2}{*}{\multicolumn{2}{|c|}{\begin{tabular}{|l|} 
Unit undertest \\
Wind Speed Input \\
\end{tabular}}} \\
\hline Frequency & & & \\
\hline $\mathrm{Hz}$ & & $\mathrm{Hz}$ & Error, $\mathrm{Hz}$ \\
\hline 100 & Yes & 100,000 & 0.02 \\
\hline 200 & Yes & 199.985 & 0.00 \\
\hline 300 & Yes & 299.943 & -0.04 \\
\hline 400 & Yos & 400,000 & 0.01 \\
\hline 500 & Yes & 500.002 & 0.01 \\
\hline 600 & Yes & 599.982 & -0.01 \\
\hline 800 & Yes & 799.995 & 0.00 \\
\hline 900 & Yes & 899.998 & 0.00 \\
\hline
\end{tabular}

Calculated slope and offset:
\begin{tabular}{|r|c|}
\hline Slope: & 1.00 \\
\hline Offset: & 0.01994328 \\
\hline
\end{tabular}

\section{Voltage Measurements}

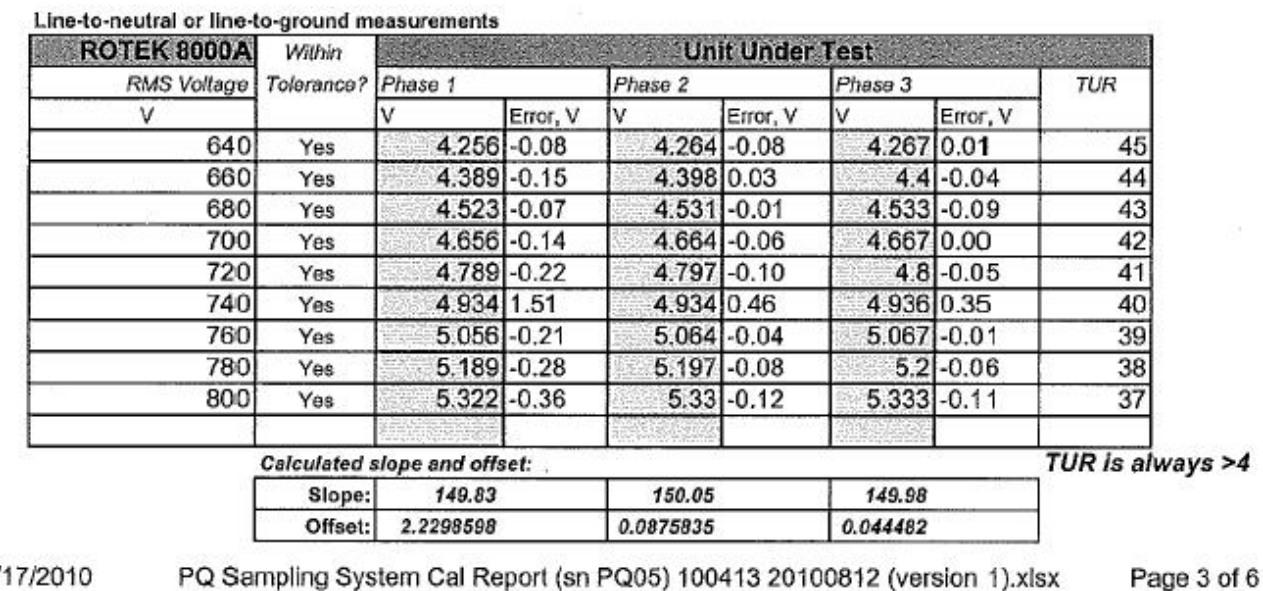

Figure A-3. Calibration sheet for the power transducer (page 3) 

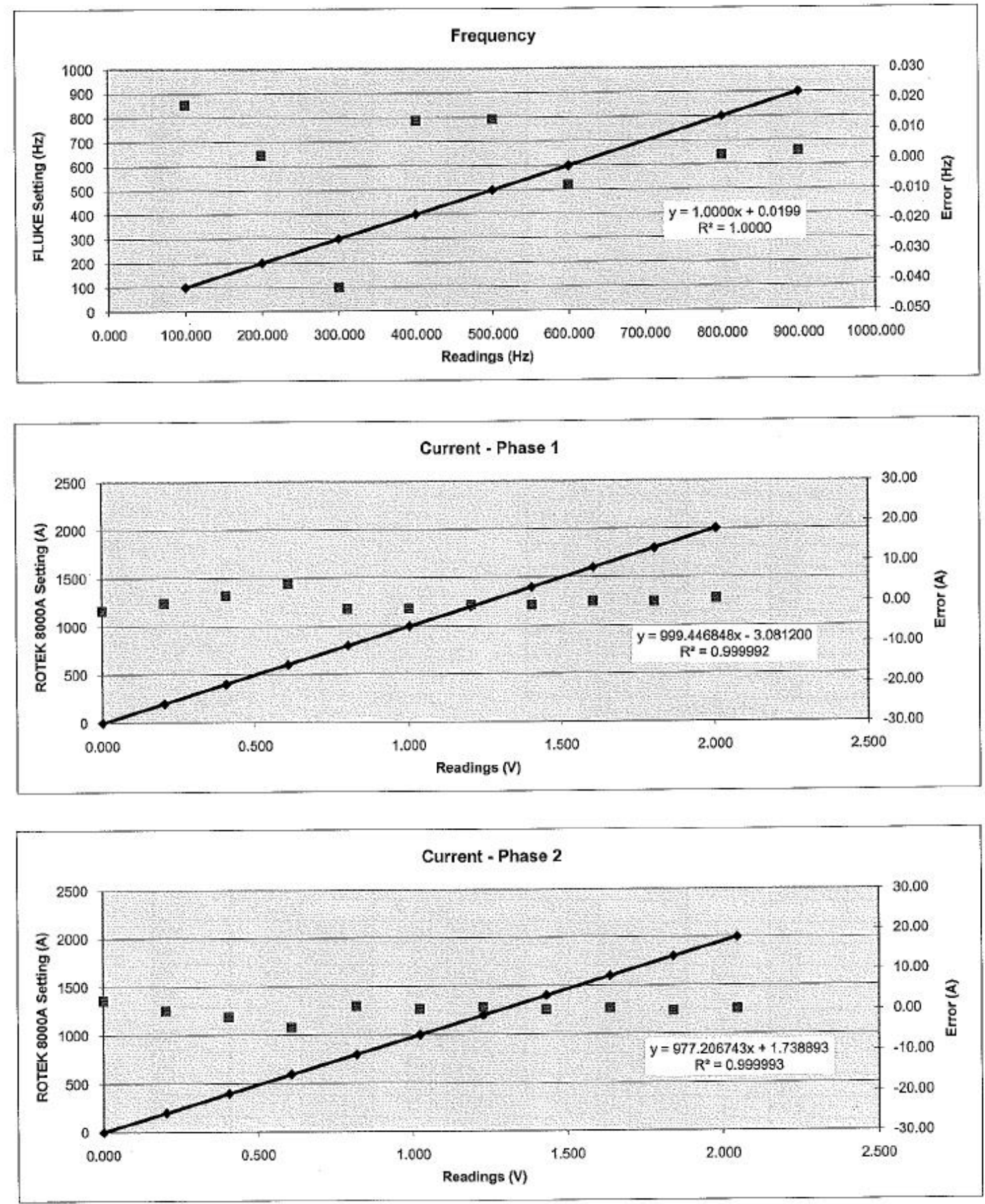

8/17/2010 PQ Sampling System Cal Report (sn PQ05) 100413 20100812 (version 1).xlsx Page 4 of 6

Figure A-4. Calibration sheet for the power transducer (page 4) 

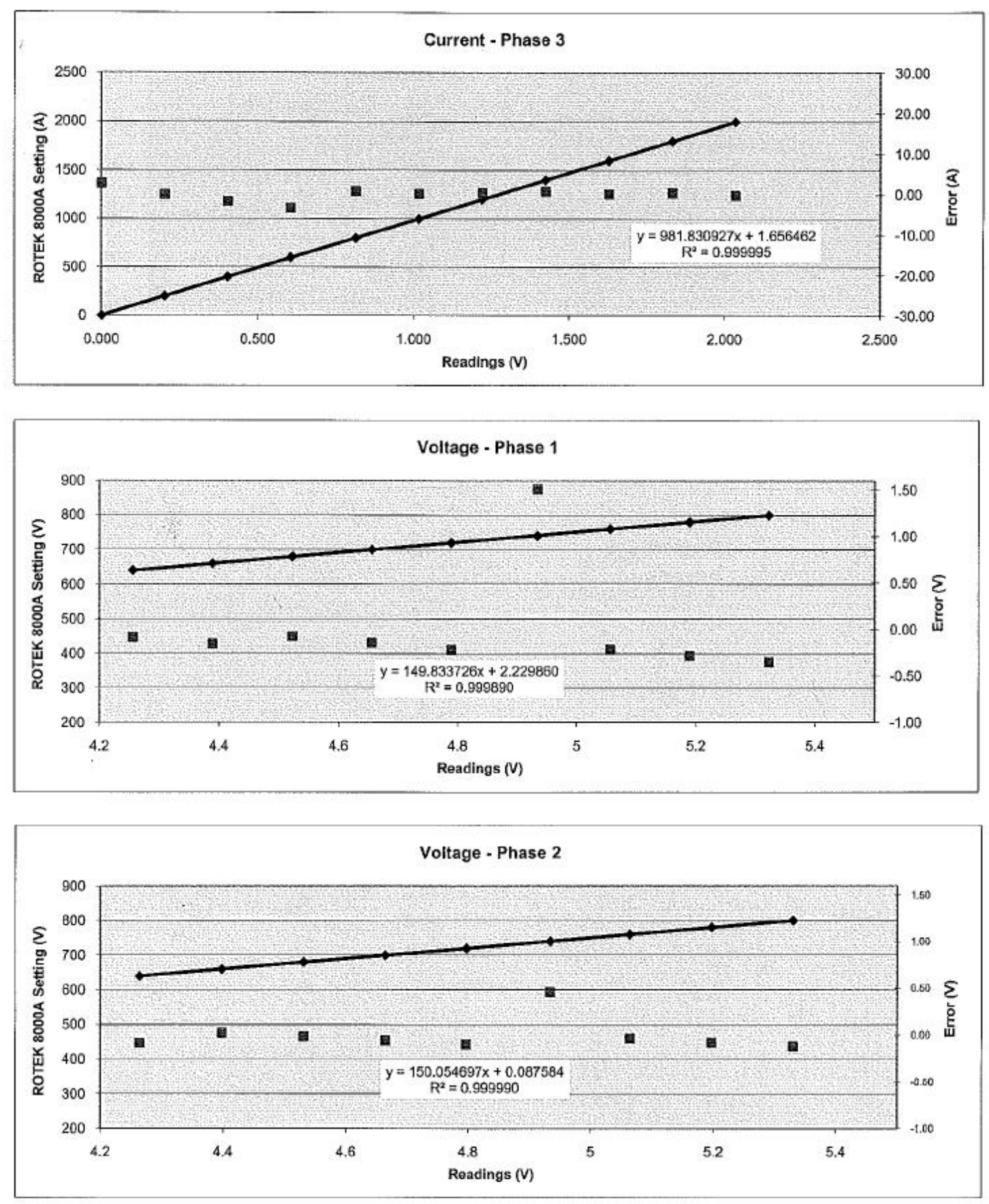

8/17/2010 PQ Sampling System Cal Report (sn PQ05) 10041320100812 (version 1).xisx Page 5 of 6

Figure A-5. Calibration sheet for the power transducer (page 5) 


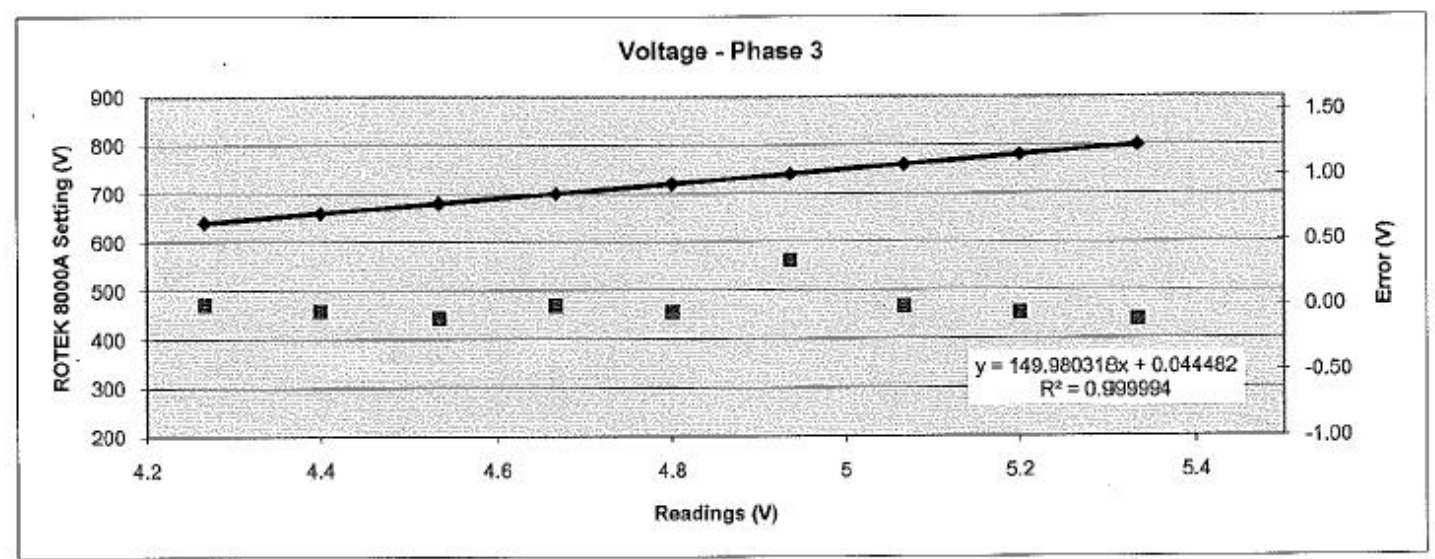

$8 / 17 / 2010$

PQ Sampling System Cal Report (sn PQ05) 10041320100812 (version 1).xlsx

Page 6 of 6

Figure A-6. Calibration sheet for the power transducer (page 6) 


\title{
Wind Speed
}

\section{DEUTSCHER KALIBRIERDIENST DKD}

Kalibrierlaboratorium / Calibration laboratory

Akkreditiert durch die / accredited by the

Akkreditierungsstelle des Deutschen Kalibrierdienstes
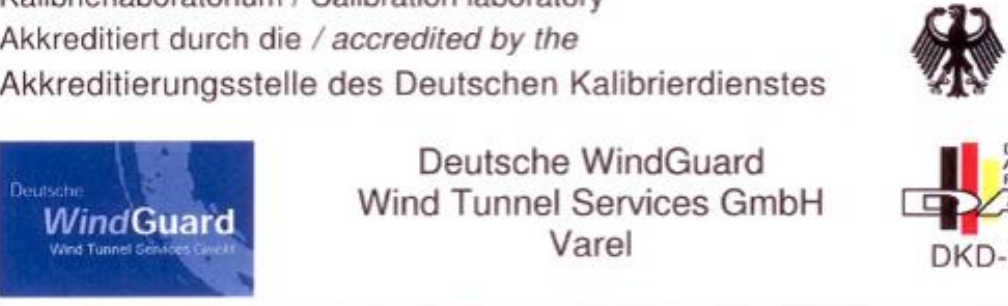

\author{
Deutsche WindGuard \\ Wind Tunnel Services $\mathrm{GmbH}$ \\ Varel
}

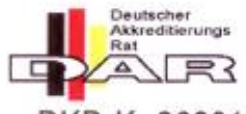

DKD-K- 36801

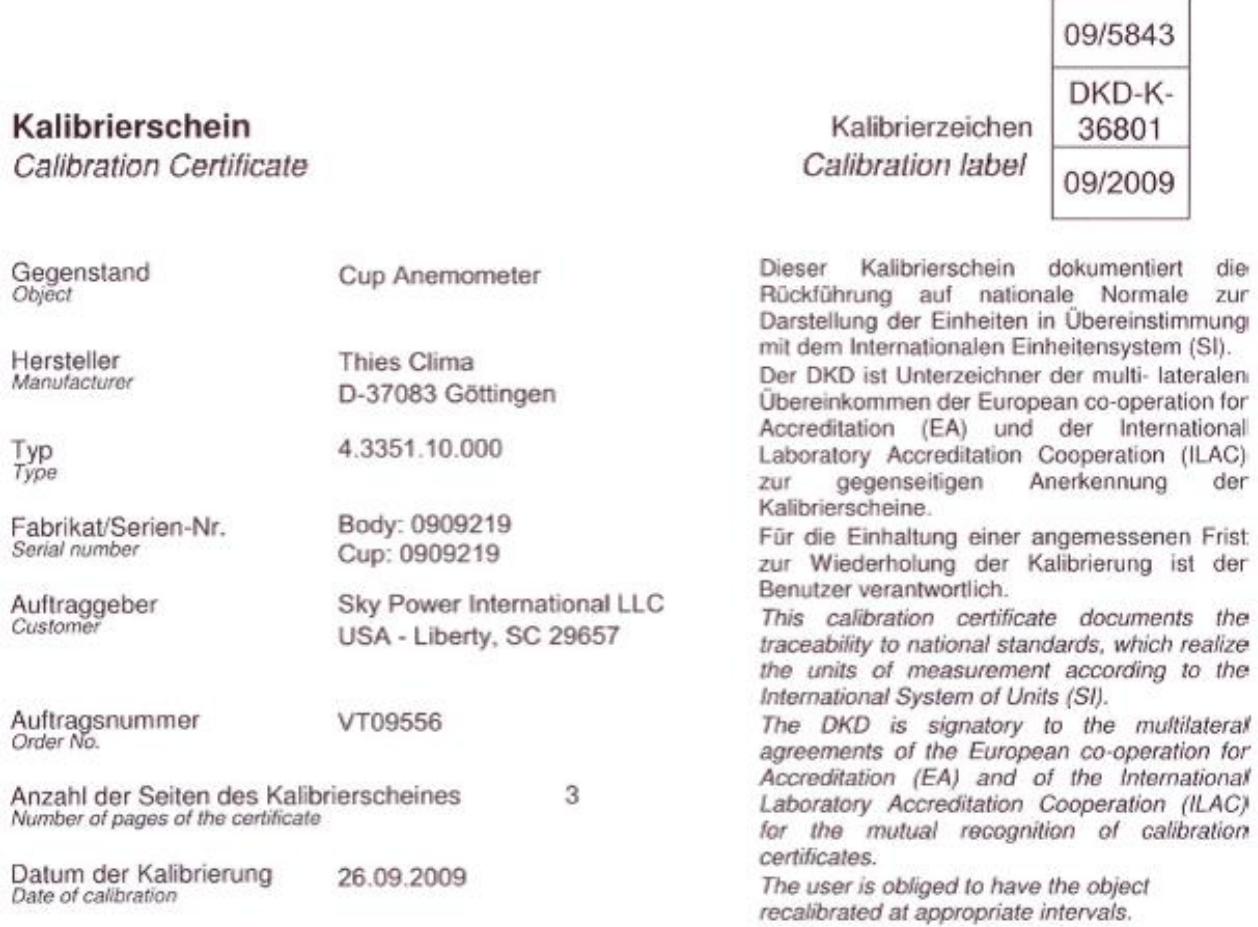

Dieser Kalibrierschein dart nur vollstăndig und unverăndert weiterverbreitet werden. Auszüge oder Änderungen bedürien der Genehmigung sowohl der Akkreditierungsstelle des DKD als auch des ausstellenden Kalibrierlaboratoriums. Kalibrierscheine ohne Unterschrift und Stempel haben keine Gültigkeit.

This calibration certificate may not be reproduced other than in full except with the permission of both the Accreditation Body of the DKD and the issuing laboratory. Calibration certificates without signature and seal are not valid.

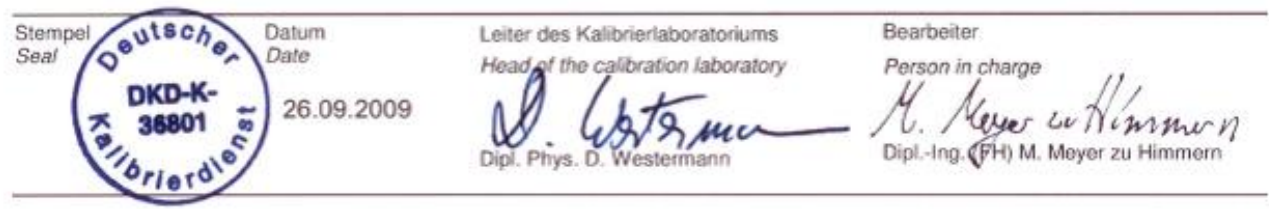

Deutsche WindGuard Wind Tunnel Services $\mathrm{GmbH}$

Oldenburger Str. 65

26316 Varel ; Tel. ++49 (0)445195150

Figure A-7. Calibration sheet for the primary anemometer (page 1) 


\section{Kalibriergegenstand} Object

Kalibrierverfahren

Calibration procedure

Ort der Kalibrierung

Place of calibration

Messbedingungen

Test Conditions

File info

\section{Umgebungsbedingungen}

Test conditions

\section{Anmerkungen}

Remarks

Auswertesoftware

Software version

"Querschnittsilache der Auslassdlise dos Windkanal:

${ }^{2}$ Vereinfachte Querschnittsfläche (Schattenwurt) des Prollings inkL. Montagerohr

" Durchmesser des Montagerohrs

4. Verhatris von 2) zu 1 )

" Korrekturtaktor durch die Verdrängung der Strômung durch den Prôlling

"Reterenzwert des Referenzanemometers bei $10 \mathrm{~m} / \mathrm{s}$ (Mittelwert)

"Aklueller Wert des Referenzanemometers

Dieser Kalibrierschein wurde elektronisch erzeugt

This calibration certificate has been generated electronically
E 61400121 - Wind Turbine Power Performance Testing 122005

MEASNET - Cup Anemometer Calibration Procedure - 091997

Windtunnel of Deutsche WindGuard, Varel

wind tunnel area ${ }^{1)} \quad 10000 \mathrm{~cm}^{2}$

anemometer frontal area ${ }^{2\}} \quad 230 \mathrm{~cm}^{2}$

diameter of mounting pipe ${ }^{3)} \quad 34 \mathrm{~mm}$

blockage ratio $^{4)} \quad 0.023[-]$

blockage correction ${ }^{5)} \quad 1.000[-]$

average WindGuard reference ${ }^{6)} \quad 203.81 /$ s (Thies First Class)

present WindGuard reference $^{7} \quad 203.71 / \mathrm{s}^{2}$

air temperature

$23.3^{\circ} \mathrm{C} \quad \pm 1.0 \mathrm{~K}$

$1027.0 \mathrm{hPa} \pm 1.0 \mathrm{hPa}$

$47.6 \% \quad \pm 2.5 \%$

Deutsche WindGuard Wind Tunnel Services GmbH

Oldenburger Str. 65

26316 Varel ; Tel. $4+49(0) 445195150$

Figure A-8. Calibration sheet for the primary anemometer (page 2) 


\section{Kalibrierergebnis:}

Result:

\begin{tabular}{|c|c|c|}
\hline Test Item (1/s) & Tunnel Speed $(\mathrm{m} / \mathrm{s})$ & Uncertainty $(\mathrm{k}=2)(\mathrm{m} / \mathrm{s})$ \\
\hline 86.363 & 4.193 & 0.10 \\
\hline 129.019 & 6.143 & 0.10 \\
\hline 170.212 & 8.052 & 0.10 \\
\hline 210.679 & 9.898 & 0.10 \\
\hline 253.862 & 11.878 & 0.10 \\
\hline 297.703 & 13.858 & 0.10 \\
\hline 339.982 & 15.828 & 0.11 \\
\hline 317.337 & 14.775 & 0.10 \\
\hline 276.809 & 12.867 & 0.10 \\
\hline 232.163 & 10.870 & 0.10 \\
\hline 190.126 & 8.932 & 0.10 \\
\hline 148.153 & 7.021 & 0.10 \\
\hline 108.825 & 5.222 & 0.10 \\
\hline
\end{tabular}

Angegeben ist die erweiterte Messunsicherheit, die sich aus der Standardmessunsicherheit durch Multiplikation mit dem Erweiterungsfaktor $k=2$ ergibt. Sie wurde gemäß DKD-3 ermittelt. Der Wert der Messgröße liegt mit einer Wahrscheinlichkeit von $95 \%$ im zugeordneten Wertintervall.

Der Deutsche Kalibrierdienst ist Unterzeichner der multilateralen Übereinkommen der European cooperation for Accreditation (EA) und der International Laboratory Accreditation Cooperation (ILAC) zur gegenseitigen Anerkennung der Kalibrierscheine. Die weiteren Unterzeichner innerhalb und außerhalb Europas sind den Internetseiten von EA (www.european-accreditation.org) und ILAC (www.ilac.org) zu entnehmen.

The expanded uncertainty assigned to the mea-surement results is obtained by multiplying the standard uncertainty by the coverage factor $k=2$. It has been determined in accordance with DKD-3. The value of the measurand lies within the assigned range of values with a probability of $95 \%$.

The DKD is signatory to the multilateral agree-ments of the European co-operation for Accredita-tion (EA) and of the International Laboratory Accreditation Cooperation (ILAC) for the mutual recognition of calibration certificates.

Figure A-9. Calibration sheet for the primary anemometer (page 3) 


\section{Detailed MEASNET ${ }^{1}$ Calibration Results}

\author{
DKD calibration no. \\ Body no. \\ Cup no. \\ Date \\ Air temperature \\ Air pressure \\ Humidity \\ Linear regression analysis \\ Slope \\ Offiset \\ St.err(Y) \\ Correlation coefficient
}

Remarks
$09 / 5843$

0909219

0909219

26.09.2009

$23.3^{\circ} \mathrm{C}$

$1027.0 \mathrm{hPa}$

$47.6 \%$

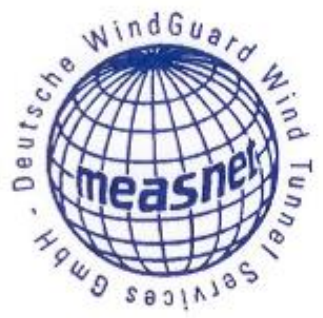

$0.045 / 9(\mathrm{~m} / \mathrm{s}) /(1 / \mathrm{s}) \pm 0.00006(\mathrm{~m} / \mathrm{s}) /(1 / \mathrm{s})$

$0.239 \mathrm{~m} / \mathrm{s} \pm 0.015 \mathrm{~m} / \mathrm{s}$

$0.017 \mathrm{~m} / \mathrm{s}$

0.999989

no

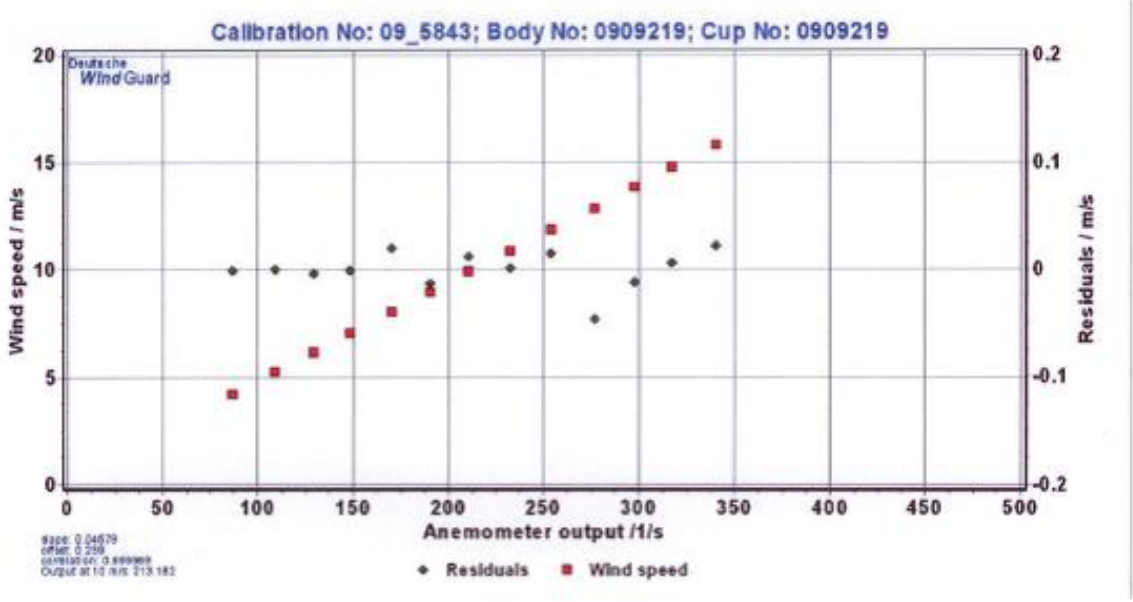

1) According to MEASNET Cup Anemometer Calibration Procedure 09/1997.

Deutsche WindGuard Wind Tunnel Services is accredited by MEASNET and by the Deutscher Kalibrierdienst - DKD ( German Calibration Service). Registration: DKD - K - 36801

Deutsche WindGuard Wind Tunnel Services $\mathrm{GmbH}$

Oldenburger Str. 65

26316 Varel ; Tel. ++49 (0)4451 95150

Wind Guard

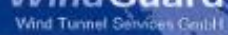

Figure A-10. Calibration sheet for the primary anemometer (page 4) 
2 Instrumentation
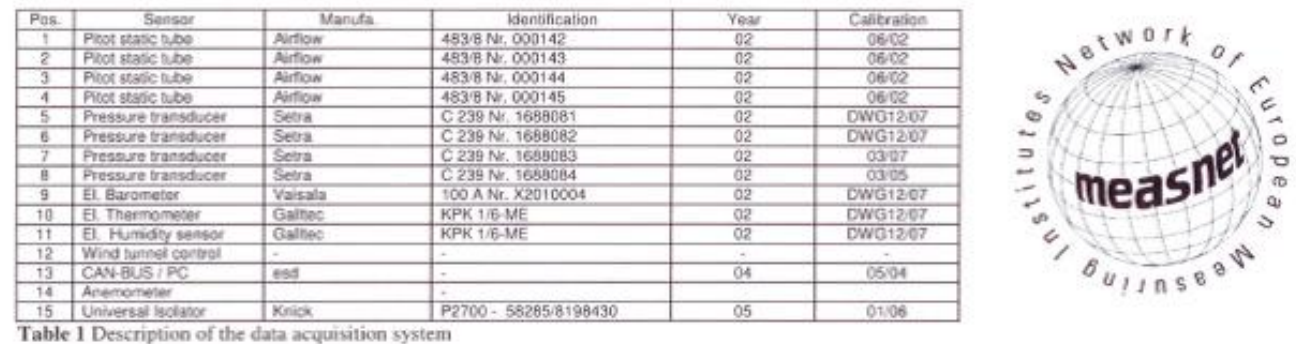

3 Photo of the calibration set-up
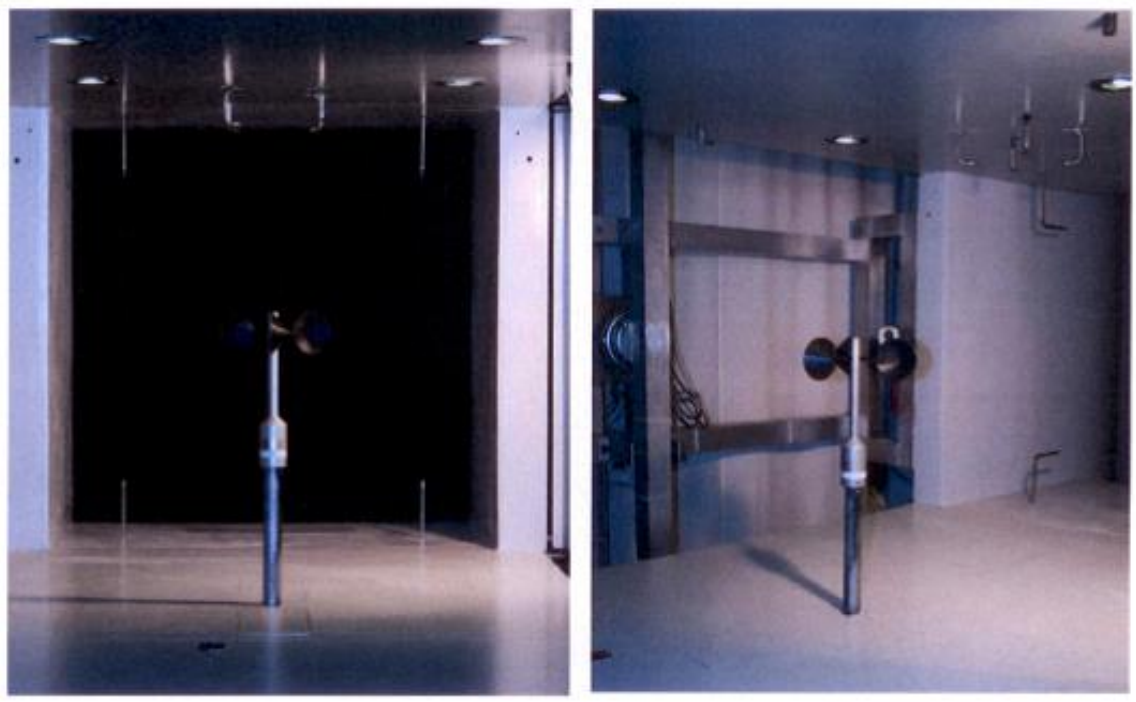

Calibration set-up of the anemometer calibration in the wind tunnel of Deutsche WindGuard, Varel.

The ansmometer shown is of the same type as the calibrated one. Remark: The proportion of the set-up are not true to scale due to imaging geometry.

4 Deviation to MEASNET procedure

The calibration procedure is in all aspects in accordance with the IEC 61400-12-1 Procedure

5 References

[1] J. Mander, D. Westermann, 12/2007 - Verlahrensanweisung DKD-Kalibrierung von Windgeschwindigkeitssensoren

[2] IEC 61400-12-1 12/2005 - Wind Turbine Power Pertormance Testing

[3] ISO 39661977 . Measurement of fluid flow in closed conduits

[4] MEASNET 091997 - Cup Anemometer Calibration Procedure

Deutsche WindGuard Wind Tunnel Services GmbH

Oldenburger Str. 65

26316 Varel ; Tel. $++49(0) 445195150$

Figure A-11. Calibration sheet for the primary anemometer (page 5) 